\title{
Breast Cancer Vaccines: Disappointing or Promising?
}

\author{
Si-Yuan Zhu ${ }^{1,2}$ and Ke-Da Yu ${ }^{1,2 *}$ \\ ${ }^{1}$ Department of Breast Surgery, Fudan University Shanghai Cancer Center, Shanghai, China, \\ 2 Shanghai Medical College, Fudan University, Shanghai, China
}

Breast cancer has become the most commonly diagnosed cancer globally. The relapse and metastasis of breast cancer remain a great challenge despite advances in chemotherapy, endocrine therapy, and HER2 targeted therapy in the past decades. Innovative therapeutic strategies are still critically in need. Cancer vaccine is an attractive option as it aims to induce a durable immunologic response to eradicate tumor cells. Different types of breast cancer vaccines have been evaluated in clinical trials, but none has led to significant benefits. Despite the disappointing results at present, new promise from the latest study indicates the possibility of applying vaccines in combination with antiHER2 monoclonal antibodies or immune checkpoint blockade. This review summarizes

OPEN ACCESS

Edited by: Fabio Bagnoli,

GlaxoSmithKline, Italy

Reviewed by:

Elizabeth Ann Repasky,

University at Buffalo, United States

Ourania Tsitsilonis,

National and Kapodistrian University of

Athens, Greece

*Correspondence:

Ke-Da Yu

yukeda@fudan.edu.cn

Specialty section:

This article was submitted to

Vaccines and

Molecular Therapeutics,

a section of the journal

Frontiers in Immunology

Received: 03 December 2021

Accepted: 12 January 2022

Published: 28 January 2022

Citation:

Zhu S-Y and Yu K-D (2022) Breast Cancer Vaccines: Disappointing or Promising?

Front. Immunol. 13:828386. doi: 10.3389/fimmu.2022.828386 the principles and mechanisms underlying breast cancer vaccines, recapitulates the type and administration routes of vaccine, reviews the current results of relevant clinical trials, and addresses the potential reasons for the setbacks and future directions to explore.

Keywords: breast cancer, vaccine, HER2, tumor antigens, E75 peptide vaccine

\section{INTRODUCTION}

Breast cancer has become the most commonly diagnosed cancer globally, with an estimated burden of 2.3 million new cases in 2020 (1). Breast cancer is heterogeneous and clinically classified into three main subtypes according to the status of estrogen receptor (ER), progesterone receptor (PR), and human epidermal growth factor receptor 2 (HER2): luminal subtype that expresses ER and/or PR, HER2-positive subtype that overexpresses HER2, and triple-negative breast cancer (TNBC) (2). Despite advances in endocrine therapy and anti-HER2 therapy in past decades, relapse and metastasis of breast cancer remain a great challenge in clinical practice. Therefore, innovative therapeutic approaches are still critically in need. In recent years, studies have shown that tumorinfiltrating lymphocyte (TIL) is associated with response to treatment and long-term prognosis in patients with breast cancer $(3,4)$. Coupled with clinical successes of immune checkpoint blockades (ICB) applied in TNBC and other solid tumors (5-7), intensive interest has arisen in immunotherapy for breast cancer $(8,9)$.

Immune-based treatment strategies can be divided into passive immunotherapy and active immunotherapy. The anti-HER2 targeted intervention via monoclonal antibodies such as trastuzumab and pertuzumab falls under the former category $(10,11)$. Active immunotherapy mainly refers to cancer vaccines. The cancer vaccine is intended to elicit or boost an anti-tumor immune response by activating autologous immune cells in the patient to induce a therapeutic effect $(12,13)$. This review summarizes the principles and mechanisms underlying breast cancer vaccines, recapitulates the type and administration routes of vaccine, and reviews the current results of 
relevant clinical trials. The challenges we face at present and potential directions to explore in the future are discussed in the end.

\section{PRINCIPLES OF BREAST CANCER VACCINE}

\subsection{Immunoediting Throughout Tumor Progression}

The immune system plays different roles in breast cancer progression during different stage of tumor development. The paradoxical interaction between the tumor and the immune system is referred to as immunoediting, which generally evolves through three phases: elimination, equilibrium, and escape (Figure 1) (14). During the elimination phase, incipient tumor cells can activate innate immunity, including maturation of macrophages, natural killing (NK) cells and dendritic cells (DCs). These cells help prime tumor-specific T cells. Thus the adaptive immune response can cooperate with innate immunity to recognize and eradicate these early transformed tumor cells. The equilibrium phase starts if any tumor subclones survives the selection pressure from the host immunity. Tumor cells can hardly be removed, but meanwhile, their progression is strictly limited or even paused because of the delicate balance between tumor growth and the defense effect of the immune system in this phase. However, tumor subclones with less immunogenicity will eventually arise due to tumor cells' genetic instability and epigenetic modifications (15). These subclones can evade immune recognition and destruction through multiple solutions such as downregulating antigen-presenting molecules and increasing immune checkpoint receptors on the cell surface $(16,17)$. Therefore, the evolved tumor cells that succeed in escaping constant immunologic pressure will enter the last phase of immunoediting, where the immune system scarcely restrict their progression (18-20).

\subsection{Immune Cells Recognizing Tumor Antigens}

To produce an anti-tumor immune response, the effector immune cells need to recognize tumor antigens presented by tumor cells directly or by antigen-presenting cells (APCs) via major histocompatibility complex (MHC) on the cell surface. $\mathrm{CD}^{+}$and $\mathrm{CD}^{+} \mathrm{T}$ cells, which play a core role in the immunoediting process, distinguish these non-self-epitopes of tumor cells displayed by MHC class-I and MHC class-II molecules respectively from normal self-antigens (21-24).

Tumor antigens can be divided into tumor-specific antigens (TSAs) and tumor-associated antigens (TAAs) (25). TSAs are expressed only by tumor cells and not by normal cells. TSAs include oncoviral antigens derived from oncogenic tumor viruses and neoantigens derived from somatic mutations in tumor cells. Therefore there is usually no immune tolerance towards TSAs in humans (26).

TAAs are self-proteins commonly expressed in both tumors and normal tissues, while their expression patterns in tumor cells are abnormal (27). This category includes overexpressed antigens such as HER2 and mucin-1 (MUC-1), tissue differentiation antigens such as carcino-embryonic antigen (CEA), and tumor germline antigens like melanoma-associated antigen (28). The majority of tumor antigens that have been studied in breast cancer vaccines so far are the HER2 protein and other HER2-derived

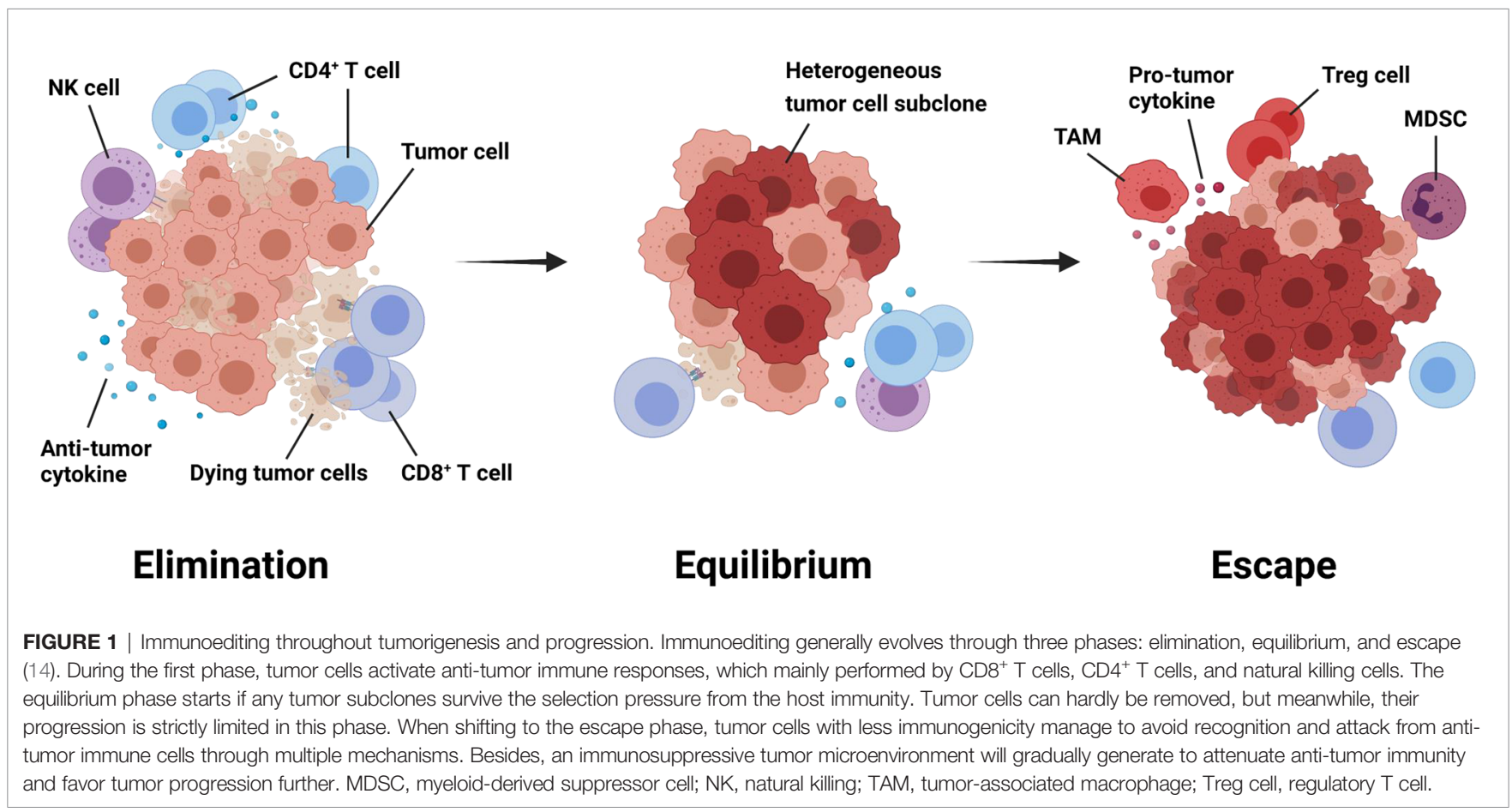


peptides $(29,30)$. In humans, the HER2 protein is generally expressed during fetal development and is weakly detectable in the epithelial cells of many normal tissues in adults (31). Thus immune tolerance to HER2 has usually been established already. In fact, despite the existence of immune tolerance, humoral and cellular immunity against HER2 have been detected in some of breast cancer patients due to the high immunogenicity of the antigen $(32,33)$. However, the level of the pre-existed anti-HER2 immunity is usually too low to induce an evident therapeutic effect. Therefore, vaccines targeting HER2-related antigens need to overcome the established tolerance to boost an immune response that is strong and durable enough (31). Various strategies, including using novel immunoadjuvants, applying dominant or subdominant epitopes, and altering the natural structure of peptides, have been investigated in breast cancer vaccines to circumvent immune tolerance.

\subsection{Tumor Cells Attenuating Anti-Tumor Immunity}

To successfully escape immunosurveillance, tumors manage to suppress the host immunity both systemically and locally (34). As mentioned above, when the elimination phase gradually shifts to the escape phase, the immunosuppressive effect will outweigh the antitumoral response in the relatively advanced stage of the disease. During this shift, suppressive immune cells, including regulatory $\mathrm{T}$ (Treg) cells, tumor-associated macrophages (TAMs), and myeloid-derived suppressor cells (MDSCs), become increasingly prevalent in the tumor microenvironment (TME) and the draining lymph nodes of the tumor and even appear in peripheral blood (35-39). Increased number of these immunosuppressive cells generally correlates to inferior prognosis (38-42). Moreover, the number and the activity of the cytotoxic lymphocytes (CTLs) and NK cells in the TME are reduced so that the antitumoral response will be further undermined (43-46).

In addition to the transformation of immune cell composition in the TME, cytokines are also involved in generating an immunosuppressive microenvironment in favor of tumor progression (47). For instance, upregulation of the DC-derived cytokine TGF $\beta$ promotes the proliferation of Treg cells (48), and Treg cells will correspondingly downregulate the co-stimulatory molecules such as CD80 and CD86 on DCs required for CTL priming (45). The cytokine interleukin-2 (IL-2), which is necessary for CTL activation, can bind to Treg cells at a higher affinity, leaving the CTLs in starvation (46). Moreover, adenosine produced by Treg cells has an immune inhibitory effect on the effector T cells $(49,50)$. The inhibitory cytokine IL-10 and TGF $\beta$ secreted by TAMs are also capable of blocking the function of CTLs $(51,52)$ and suppress the production of anti-tumor cytokine IL-12 (53).

Furthermore, immune checkpoint receptors such as programmed cell death receptor 1 (PD-1) and cytotoxic $\mathrm{T}$ lymphocyte antigen 4 (CTLA-4) are found to be upregulated in tumor progression. PD-1 is the counter-receptor of programmed cell death ligand 1 (PD-L1) (54). In patients with different malignant tumors, high levels of PD-1 expression are detected in TILs, including tumor-specific $\mathrm{T}$ cells, and PD-L1 is upregulated in tumor cells and APCs simultaneously. Engagement of PD-L1 and
PD-1 results in T cell dysfunction and apoptosis so that the tumor cells can avoid destruction from T cells $(55,56)$. CTLA-4 is found in the intracellular compartment in resting $\mathrm{T}$ cells and it will be transported to the cell surface once the T cell is stimulated (57). It can block the co-stimulatory signals, which is essential for $\mathrm{T}$ cell activation, through binding the transmitting molecules CD80 and CD86 on DCs and B cells to prevent the immune response from over-amplification (58). ICB blocks the inhibitory receptors such as PD-1/PD-L1 and CTLA-4, allowing effector T cells to attack the tumor (59). The efficacy of ICB for breast cancer has recently been evaluated. Monoclonal antibody atezolizumab targeting PD-L1 successfully prolonged progression-free survival (PFS) among patients with metastatic TNBC in the IMpassion130 trial (7). However, the same drug failed to show a significant improvement in PFS for advanced HER2-positive breast cancer in combination with trastuzumab emtansine in the KATE2 trial (60).

Collectively, the suppressive immune cells, the cytokines, the metabolites, and immune checkpoint molecules together constitute a complex network of immune suppression that facilitates immune escape and attenuates anti-tumor immunity.

\section{APPROACHES OF BREAST CANCER VACCINE}

Strategies of vaccination involve optimization of vaccine regimens and administration routes. Breast cancer vaccines can be divided into different types based on platforms and formulations. Nevertheless, they all need to make the targeted antigen recognized by the autologous immune system to induce a therapeutic effect. Adjuvant of the vaccine plays a vital role as they are able to enhance antigen immunogenicity and regulate the immune response. Additionally, administration routes have different influences on the delivery of targeted antigens to DCs. We will briefly review the types of breast cancer vaccines and introduce the adjuvants and administration routes applied currently.

\subsection{Types of Breast Cancer Vaccine}

Currently, the most common vaccination approach for breast cancer is to utilize peptides derived from tumor antigens. Vaccination of tumor antigen-related protein and carbohydrate has also been explored for long. Tumor cell-based vaccine is one of the traditional methods, while DNA-based and DC-based vaccines represent novel modalities in this field. A different formulation of vaccines and their mechanisms of action are depicted in Figure 2.

\subsubsection{Peptide Vaccine}

Delivering MHC class-I restricted peptide epitopes to activate immune responses against the specific tumor antigen is one of the most common strategies applied for breast cancer. The peptide injected will be processed and presented by APCs to prime immune effector cells, which will then seek out and eradicate cancer cells expressing the shared antigen (61). Compared to other formulations, short amino acid peptides are simple and cheap to manufacture and relatively stable 


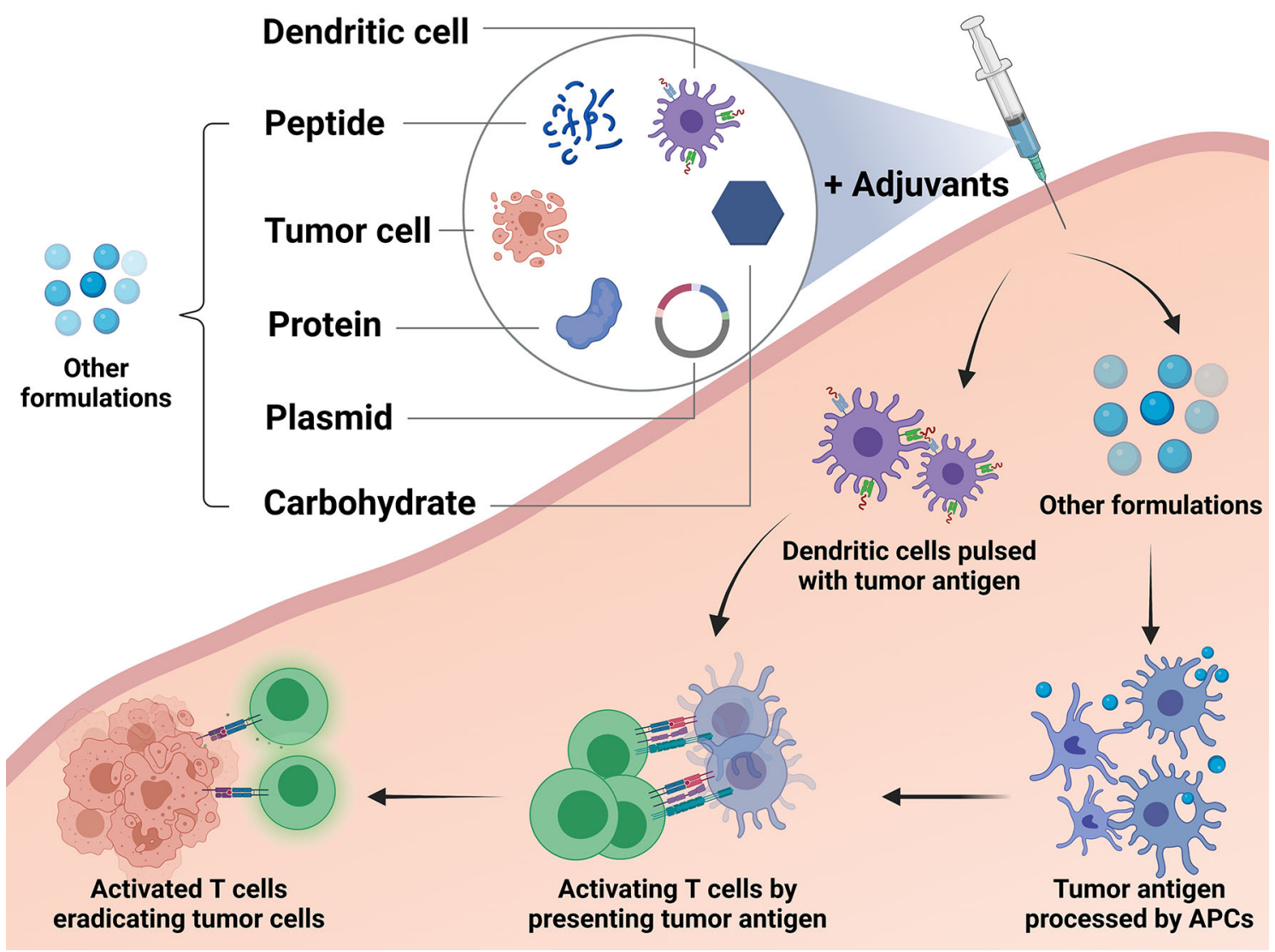

FIGURE 2 | Different types of breast cancer vaccines and their mechanisms. The studied breast cancer vaccines can be divided into the following types according to their formulations and approaches: peptide vaccine, protein-based vaccine, carbohydrate antigen vaccine, DNA-based vaccine, dendritic cell-based (DC-based) vaccine, and tumor cell vaccine. DC-based vaccines utilize ex vivo generation of DCs loaded with tumor antigens or transfected to express tumor antigens. These cells process the antigens and present them to T cells directly by themselves in order to activate an immune response. Except the dendritic cells, other formulations applied in the vaccines, including peptide, protein, plasmid, carbohydrate and tumor cell, need to stimulate the autologous antigen presenting cells (APCs). Then the autologous APCs will activate the effector immune cells to boost an anti-tumor reaction.

when transported, which makes large-scale manufacture and transportation possible (62). However, the individual peptide is usually limited to certain human leukocyte antigen (HLA) subtypes and thus patients who do not express the common HLA types cannot be treated with the vaccine (63). In addition, the usual MHC class-I binding peptides do not have a strong ability to activate $\mathrm{CD} 4^{+}$helper T cells, which may cause limited activation of $\mathrm{CD}^{+}$cytotoxic $\mathrm{T}$ cells and transience of immune responses (64). This issue might be partly overcome by using synthetic peptides that are long enough to include multiple MHC class-I and class-II epitopes. Such peptides containing 23-45 amino acids might lead to superior $\mathrm{T}$ cell stimulation through a more efficient processing and presentation pathway (65).

\subsubsection{Protein-Based Vaccine}

The protein-based vaccine is developed with the whole or shortened fragment of tumor antigen protein whose amino acid sequence is much longer than peptides (64). It enables uptake, processing, and presentation of multiple MHC class-I and class-II peptide epitopes and is not HLA restricted. But the presentation process might be less efficient, and the response to this kind of vaccine is hard to measure due to lack of a specific marker (66).

\subsubsection{Carbohydrate Antigen Vaccine}

Carbohydrate antigens abnormally expressed by tumor cells can also be distinguished by immune cells. Hence, such carbohydrate antigen becomes an ideal candidate to incorporate in a cancer vaccine. For instance, Sialy-Tn (STn), a disaccharide carbohydrate associated with MUC-1, is expressed uniquely on the cell surface of a variety of cancer cells, including breast cancer (67). Immunization with STn demonstrated tumor regression and prolonged survival in animal studies, and the cancer vaccine towards STn was correspondingly developed (68).

\subsubsection{Tumor Cell Vaccine}

It is one of the earliest approaches of the cancer vaccine to use whole tumor cells or products of tumor cell lysis to stimulate an 
immune response (64). It is based on a pool of unknown antigens derived from autologous or allogeneic tumor cells, and thus a polyvalent immune response will be triggered. The tumor cells are modified to secret cytokines or express co-stimulatory molecules in order to enhance the antigen-presenting ability in some vaccines $(69,70)$. The disadvantage of the tumor cell vaccine lies in that these vaccines contain endogenous cellular antigens and may cause an autoimmune reaction. There is also a lack of a standardized method for preparing tumor cell vaccines (63).

\subsubsection{DNA-Based Vaccine}

The DNA-based breast cancer vaccine uses the DNA sequence encoding tumor antigens, which are usually delivered in the forms of plasmids or vectors. The DNA sequence will be incorporated by APCs and translated into the tumor antigen, which will then be processed for presentation for immune cells to stimulate an antigen-specific immunity (71). DNA-based vaccines are easy to construct in large quantities and store at a low cost. However, the immunogenicity is not strong enough due to low efficiency of plasmids uptake and antigen expression $(63,71)$.

\subsubsection{DC-Based Vaccine}

DCs are a heterogeneous population of APCs that efficiently take up antigens and then process and present the antigens to $\mathrm{CD} 4^{+}$ and $\mathrm{CD}^{+} \mathrm{T}$ cells after migrating to lymph nodes. NK cells and $\mathrm{B}$ cells can also be stimulated by DCs (61). The DC-based vaccines usually utilize ex vivo generation of DCs loaded with tumor antigens or transfected to express tumor antigens. Monocytes and $\mathrm{CD} 34+$ progenitor cells have been tested, and antigens including complex tumor lysates and multiple MHC class-I and class-II peptides have been explored in studies (62). Some vaccines require inoculation in lymph nodes and the DCs delivered can activate the immune cells directly. The production of DC-based vaccines can be technically demanding due to the individualized ex vivo process for the maturation of DCs (64). It is therefore difficult to compare trials with a single clinical trial arm and individualized vaccination patterns.

\subsubsection{DC-Tumor Cell Fusion Vaccine}

One of the efforts to improve the DC-based vaccination strategy is the fusion of DCs with tumor cells. DC-tumor cell hybrids can be created by exposing DCs and tumor cells in polythelene glycol (72). Tumor cells can also be transfected with a viral fusogenic membrane glycoprotein and pelleted with DCs to achieve a DCtumor hybrid (73). Besides, electrofusion technique has been applied in this strategy (74). Compared with DCs pulsed with single antigens, DC-tumor cell fusion is able to present the entire repertoire of tumor antigens from the parental tumor cell to activate both the MHC class-I and class-II pathways (75). Nevertheless, this kind of vaccine is even harder to produce compared to the DC-based vaccine pulsed with peptides.

\subsection{Adjuvants for Breast Cancer Vaccine}

Adjuvants are substances that enhance antigen immunogenicity and elicit an immune response when inoculated with antigens (76). Mechanisms of most adjuvants include slowing release of antigens, promoting antigen uptake and presentation of APCs and stimulating proliferation of DCs and macrophages (77-79). In prophylactic vaccines designed for infectious diseases, classical adjuvants, such as alum, mainly induce the type $2 \mathrm{~T}$ helper celldependent humoral immunity instead of type $1 \mathrm{~T}$ helper cell responses that directly destruct tumor cells (80). Different types of adjuvants used in cancer vaccines are listed in Table $\mathbf{1 .}$

Granulocyte-macrophage colony-stimulating factor (GM-CSF) is a secreted cytokine that has been widely used as an adjuvant in breast cancer vaccines. It has been shown to be capable of triggering the maturation of myeloid cells such as granulocytes and macrophages and promoting the expansion and activation of DCs $(81,82)$. Several breast cancer vaccines containing GM-CSF induced detectable immune responses in clinical trials (83-87). And in melanoma patients, locally addition of GM-CSF modestly increased the immune response towards the vaccinated antigen (78, 88). However, in other studies, it was also observed that GM-CSF might be associated with a lower degree of $\mathrm{T}$ cell responses and induction of inhibitory MDSCs $(89,90)$. Therefore, the application of GM-CSF as an adjuvant in cancer vaccines still needs further investigation.

Another popular strategy for adjuvants adopted in DNAbased cancer vaccines is utilizing recombinant viral vectors. Recombinant viral vectors, which usually function as a delivery vehicle for the antigen, can boost immune response as well in that they always contain more or less toll-like receptor (TLR) ligands and pattern recognition receptor ligands to activate DCs (91). The TLR agonists are also able to enhance $\mathrm{CD} 8^{+} \mathrm{T}$ cell activation and prevent $\mathrm{T}$ cell from exhausting $(92,93)$. The main drawback of such an adjuvant is that the vectors also have other sequences capable of competing with the inserted sequence of targeted antigens (94).

TABLE 1 | Major types of adjuvants for breast cancer vaccine and their functions.

\begin{tabular}{|c|c|c|}
\hline Types of Adjuvants & Examples & Functions \\
\hline Cytokines & GM-CSF, IL-12 & Promoting the maturation and activation of DCs and enhancing antigen uptake and presentation \\
\hline Microbes and microbial derivatives & BCG, CpG, MPL, poly I:C & Activating DCs through toll-like receptor ligands \\
\hline Mineral salts & Alum & Enhancing antibody production by plasma cells \\
\hline Oil emulsions or surfactants & AS02, Montanide, QS21 & Decelerating release of antigens and stimulating local DCs at the injection site \\
\hline Particulates & ASO4, polylactide co-glycolide & Functioning as an antigen carrier and enhancing antigen uptake and presentation \\
\hline Viral vectors & Adenovirus, fowlpox & Delivering antigens and activating DCs through toll-like receptor ligands \\
\hline
\end{tabular}

AS, adjuvant system; BCG, Bacillus Calmette-Guérin; CpG, cytosine-phosphate diester-guanine; DC, dendritic cell; GM-CSF, Granulocyte-macrophage colony-stimulating factor; IL, interleukin; MPL, monophosphoryl lipid A; QS21, a plant extract derived from Quillaja saponaria. 
Nevertheless, difficulty exists when comparing different adjuvant strategies for cancer vaccines since the effects of adjuvants might vary with vaccine formulations, targeted tumor antigens, immunization schedule, and route of administration. Therefore relevant studies on the optimization of adjuvants for breast cancer vaccines are urgently necessary at present.

\subsection{Administration Routes of Breast Cancer Vaccine}

Administration routes of cancer vaccines help effectively present the antigens to autologous APCs. Different preferred routes were applied for cancer vaccines of different types (Figure 3). Several peptide vaccines targeting HER2 have adopted intradermal vaccination strategies as there is a dense network of cutaneous DCs (83-85). Studies demonstrated that intradermal inoculation with low doses of the peptide was safe and stimulated antigenspecific $\mathrm{T}$ cell responses in the majority of the healthy population (95). The subcutaneous injection was also practiced in a variety of different breast cancer vaccines and achieved immune responses. However, large volumes of antigen delivered subcutaneously with adjuvants might cause severe injectionsite reactions with occasional sterile abscess formation (96), which may lead to discontinuation of vaccination procedure or reduction of vaccine doses. In addition, intramuscular administration was often used to deliver vectors or plasmids for some DNA-based vaccines (97-99). By contrast, some DCbased vaccines required intranodal injection in order to prime the $\mathrm{T}$ cells existing in the lymph node directly.

An important factor to consider is how administration routes of vaccines affect the circulating and homing process of $\mathrm{T}$ cells towards the cancer-infiltrated tissues. Recent studies showed that intranasal immunization with DCs from the lung parenchyma was able to trigger homing properties on induced $\mathrm{CD} 8^{+} \mathrm{T}$ cells to the mucosa (100). Much more work is necessary to establish valid rules regarding the delivery routes of cancer vaccines.

\section{CLINICAL TRIALS OF BREAST CANCER VACCINE}

Some breast cancer vaccines managed to elicit detectable immune responses and demonstrate good tolerance in early trials. Nevertheless, none of them has demonstrated significant clinical benefits in the following phase 3 trials. The Theratope ${ }^{\circledR}$ (STn) vaccine applied in the metastatic setting and the NeuVax $^{\text {TM }}$ [Nelipepimut-S (NPS), or E75] vaccine applied in the adjuvant setting both failed to bring clinical benefits in their

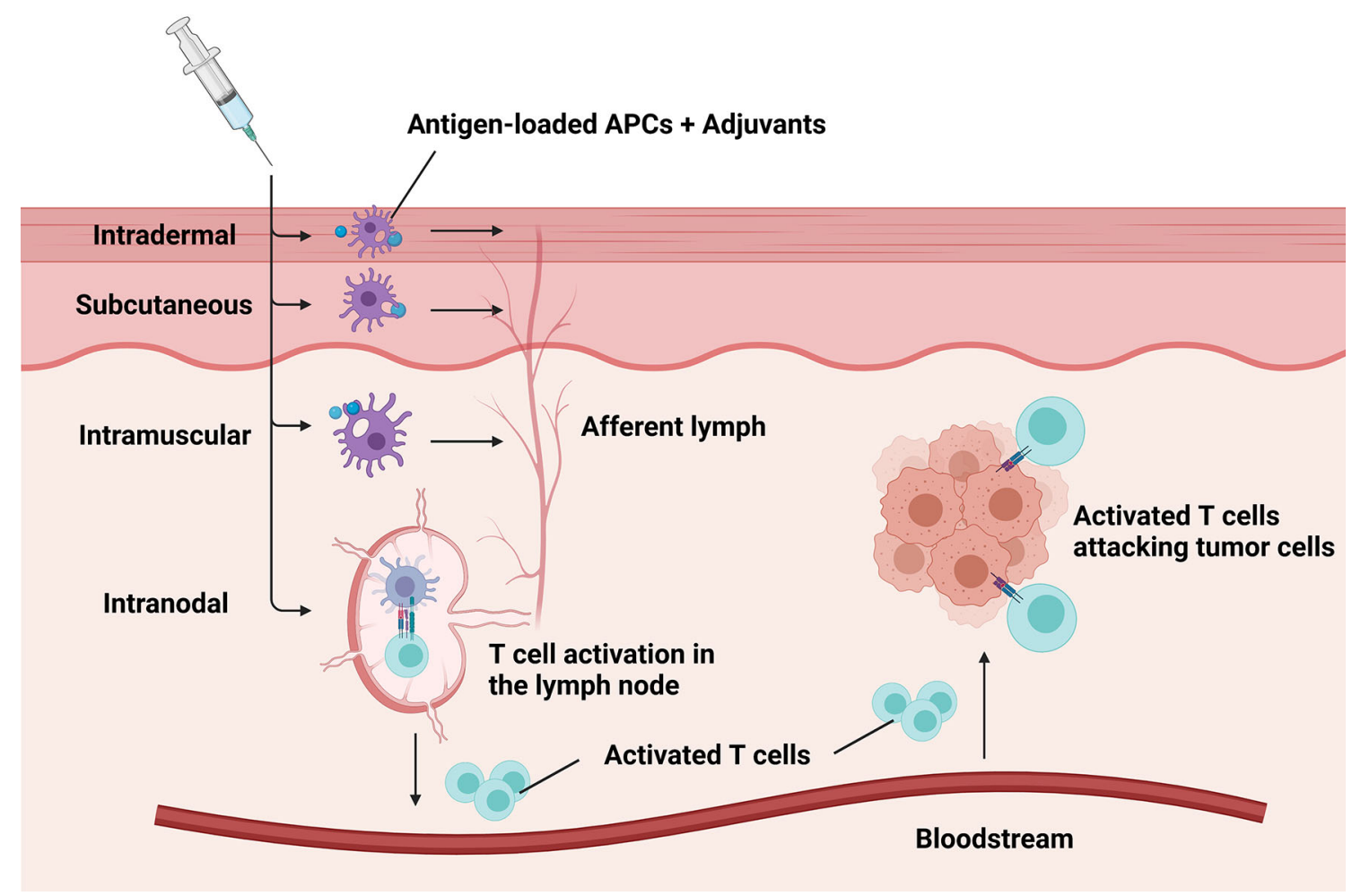

FIGURE 3 | Different administration routes of breast cancer vaccines. Major administration routes of breast cancer vaccines include intradermal, subcutaneous, intramuscular, and intranodal injection. The preferred routes depending on the type of the delivered antigens help effectively present the antigens to autologous antigen-presenting cells (APCs). Then the antigen-loaded APCs transfer to lymph nodes to prime T cells through afferent lymph. Subsequently, activated T cells transport into tumorous tissue with the aid of the bloodstream to eradicate tumor cells. 
phase 3 study despite their early success (101, 102). We summarize the current results of clinical trials evaluating breast cancer vaccines according to the antigen they target in the following paragraphs. Major clinical trials targeting HER2related antigens and non-HER2-related antigens are listed in Tables 2 and 3, respectively.

\subsection{Vaccines Targeting HER2-Related Antigens}

Breast cancer vaccines deliver HER2 or HER2-related antigens through different approaches and formulations. In this field, several peptide vaccines have been studied extensively in phase 2-3 clinical trials. We will introduce the vaccines targeting HER2-related antigens in the order of their types.

\subsubsection{Peptide Vaccine-E75}

E75 (Nelipepimut-S) vaccine is one of the most extensively studied breast cancer vaccines against HER2. It consists of HLA-A2/A3-restricted, MHC class-I, extracellular HER2derived peptide E75 and the immunologic adjuvant GM-CSF. In a phase 1 trial initiated in the adjuvant setting, the E75 vaccine was administered to the disease-free patient with any level of HER2 expression [immunohistochemistry (IHC) 1-3+]. An immune response with good tolerance was demonstrated (83). The monthly intradermal dose of 1000mg E75 and 250mg of GM-CSF for 6 months was determined to be optimal (116). In the following phase 2 adjuvant study, 195 patients were randomly assigned to the vaccination arm or the control arm. At the conclusion of 5-year follow up, the disease-free survival (DFS) rate was $89.7 \%$ for vaccinated patients and $80.2 \%$ for control patients $(\mathrm{P}=0.08)(103,116)$. Interestingly, vaccinated patients with relatively low expression of HER2 (IHC 1-2+) demonstrated a more robust immune response compared to those with higher levels of HER2 expression (IHC 3+), suggesting the possibility of immunologic tolerance to HER2 in some patients with tumors expressing high levels of HER2 (117).

Based on these promising data, the multicenter doubleblinded phase 3 PRESENT trial was undertaken in patients with node-positive breast cancer with IHC 1-2+ HER2 expression in the adjuvant setting (102). In total, 758 diseasefree patients were randomized to receive NeuVax ${ }^{\mathrm{TM}}$ or placebo. The primary endpoint was 3-year DFS. However, this trial was terminated due to futility when an interim analysis, which was triggered after 70 qualifying DFS events occurred, failed to show a significant difference in DFS with vaccination. There were even more DFS events in the vaccinated group than in the control group. Still, the deaths, second cancers, and clinical recurrences were similar at 16.8 months median follow-up.

When combined with anti-HER2 targeted therapy, the efficacy of E75 vaccine in patients with low expression of HER2 (IHC 1-2+) was evaluated in a recently conducted phase 2 adjuvant trial (104). A total of 275 patients were randomized to receive E75 or placebo after receiving 1-year standard trastuzumab-based anti-HER2 treatment. At a median follow up of 25.7 months, estimated DFS did not significantly differ between the vaccination arm and the control arm $(\mathrm{P}=0.18)$. But significant improved DFS was seen in patients with TNBC (IHC
$1-2+$ and hormone receptor-negative) in a planned exploratory analysis $(P=0.01)$. This study reflects that the HER2-derived peptide vaccines might be effective when used in parallel to or combined with trastuzumab-based anti-HER2 targeted therapy.

As for HER2 overexpression (IHC 3+) patients, the efficacy of E75 remains ambiguous in that the majority of the HER2 overexpression patients enrolled in the existing trials did not receive trastuzumab as standard anti-HER2 therapy.

\subsubsection{Peptide Vaccine-GP2}

Although the results of $\mathrm{NeuVax}^{\mathrm{TM}}$ are not satisfying, new promise comes from other latest studies. GP2 is another HLAA2/A3-restricted, MHC class-I, an immunogenic peptide derived from the transmembrane domain of HER2. While GP2 has a lower affinity to HLA-A2 than E75, it is as efficacious in inducing a $\mathrm{CD}^{+} \mathrm{T}$ cell response (118). The GP2 vaccine demonstrated a good safety profile and managed to generate GP2-specific T cell responses and GP2-specific delayed-type hypersensitivity (DTH) responses when administered with GM-CSF in a phase 1 adjuvant trial (84). In the following phase 2 adjuvant trial that enrolled 180 patients with tumors expressing HER2 (IHC 1-3+), no significant benefit in DFS in the vaccination group compared with the control group ( $88 \%$ vs. $81 \%, \mathrm{P}=0.43$ ) after a 34 -month median follow-up was observed (105). A subgroup analysis showed that HER2-positive (IHC 3+) patients had no recurrences with a trend towards improved DFS in the vaccinated group as compared to the control group (100\% vs. $87.2 \%, \mathrm{P}=0.052$ ) (119). Encouraging results came from the final analysis of this trial, which demonstrated that the GP2 vaccine reduced the recurrence rate to $0 \%$ in HER $3+$ patients, who have received a standard course of trastuzumab after surgery. The estimated 5-year DFS rate in the 46 HER2 3 + vaccinated patients, if the patient completed the primary immunization series, was $100 \%$ versus $89.4 \%$ in the 50 placebo patients $(p=0.034)(106)$.

\subsubsection{Peptide Vaccine-AE37}

In addition to E75 and GP2, AE37 is another HER2-related peptide vaccine used in the adjuvant setting of breast cancer. It is an Ii-Key hybrid of AE36, which is derived from the intracellular domain of HER2. The modification was conducted to improve the binding potency of the epitope (120). Unlike E75 and GP2, AE37 is an MHC class-II epitope that mainly induces $\mathrm{CD}^{+} \mathrm{T}$ cell activation. Low toxicity and favorable immune response were demonstrated in a phase 1 trial (85). Levels of Treg cells were measured and found to decrease after vaccination as AE37 stimulates $\mathrm{CD}^{+}$helper $\mathrm{T}$ cell response (121). In a phase 2 trial of clinically disease-free patients expressing any degree of HER2 (IHC 1-3+), AE37 plus GM-CSF and GM-CSF alone were randomly administered to 153 and 145 patients, respectively (107). The DFS rate was $87.6 \%$ in the vaccine group and $86.2 \%$ in the control group $(\mathrm{P}=0.70)$ after a median follow-up of 30 months. In planned subset analyses of patients with IHC 1-2+ HER2-expressing tumors, DFS was $86.8 \%$ in vaccinated patients and $82.0 \%$ in control patients $(\mathrm{P}=0.21)$. Interestingly, TNBC patients (IHC 1-2+ and hormone receptor-negative) demonstrated a DFS rate of $84.0 \%$ in the vaccine group and $64.0 \%$ in the control group $(\mathrm{P}=0.12)$, suggesting $\mathrm{AE} 37$ 
TABLE 2 | Major clinical trials on breast cancer vaccines targeting HER2-related antigens.

\begin{tabular}{|c|c|c|c|c|c|c|c|}
\hline $\begin{array}{l}\text { Clinical Trial } \\
\text { Reference }\end{array}$ & $\begin{array}{c}\text { Trial } \\
\text { Phase }\end{array}$ & Setting & $\begin{array}{l}\text { Targeted } \\
\text { Tumor } \\
\text { Antigen }\end{array}$ & Design and Arms & $\begin{array}{l}\text { Breast Cancer } \\
\text { Subtype }\end{array}$ & $\begin{array}{c}\text { Primary } \\
\text { Objectives }\end{array}$ & Outcomes \\
\hline $\begin{array}{l}\text { PRESENT Trial } \\
\text { NCT01479244 } \\
\text { (102) }\end{array}$ & III & Adjuvant & $\begin{array}{l}\text { HER2- } \\
\text { derived } \\
\text { peptide } \\
\text { E75 }\end{array}$ & $\begin{array}{l}\text { Vaccination Arm: E75 + } \\
\text { GM-CSF }(\mathrm{N}=376) \\
\text { Control Arm: Placebo + } \\
\text { GM-CSF }(\mathrm{N}=382)\end{array}$ & $\begin{array}{l}\text { HLA-A2/A3+, } \\
\text { HER2 low- } \\
\text { expressing (IHC 1/ } \\
\text { 2+), node-positive }\end{array}$ & DFS & $\begin{array}{l}\text { RR at } 16.8 \text { months interim analysis: } 9.8 \% \\
\text { (vaccinated group) versus } 6.3 \% \text { (control group) } \\
\text { ( } P=0.07 \text { ). Based on these data, the study } \\
\text { was terminated for futility. }\end{array}$ \\
\hline $\begin{array}{l}\text { US Military Cancer } \\
\text { Institute Clinical } \\
\text { Trials Group Study } \\
\text { I-01 and I-02 (103) }\end{array}$ & $|/| \mid$ & Adjuvant & $\begin{array}{l}\text { HER2- } \\
\text { derived } \\
\text { peptide } \\
\text { E75 }\end{array}$ & $\begin{array}{l}\text { Vaccination Arm: E75 + } \\
\text { GM-CSF of different } \\
\text { doses ( } N=108) \\
\text { Control Arm: Observation } \\
(\mathrm{N}=79)\end{array}$ & $\begin{array}{l}\text { HLA-A2/A3+, } \\
\text { HER2-expressing, } \\
\text { node-positive or } \\
\text { high-risk node- } \\
\text { negative }\end{array}$ & $\begin{array}{l}\text { Safety, } \\
\text { optimal } \\
\text { dosing of } \\
\text { immune } \\
\text { response }\end{array}$ & $\begin{array}{l}\text { Five-year DFS: } 89.7 \% \text { (vaccinated group) } \\
\text { versus } 80.2 \% \text { (control group) }(P=0.08) \text {. } \\
\text { Toxicities were minimal. }\end{array}$ \\
\hline $\begin{array}{l}\text { NCT01570036 } \\
\text { (104) }\end{array}$ & $\|$ & Adjuvant & $\begin{array}{l}\text { HER2- } \\
\text { derived } \\
\text { peptide } \\
\text { E75 }\end{array}$ & $\begin{array}{l}\text { Vaccination Arm: E75 + } \\
\text { GM-CSF + trastuzumab } \\
(\mathrm{N}=136) \\
\text { Control Arm: Placebo + } \\
\text { GM-CSF + trastuzumab } \\
(\mathrm{N}=139)\end{array}$ & $\begin{array}{l}\text { HLA-A2/A3+, } \\
\text { HER2 low- } \\
\text { expressing (IHC 1/ } \\
\text { 2+), node-positive }\end{array}$ & DFS & $\begin{array}{l}\text { The estimated } 24 \text {-month DFS: } 89.8 \% \\
\text { (vaccinated group) versus } 83.8 \% \text { (control } \\
\text { group) }(P=0.18) \text {. }\end{array}$ \\
\hline $\begin{array}{l}\text { NCT00524277 } \\
(105,106)\end{array}$ & $\|$ & Adjuvant & $\begin{array}{l}\text { HER2- } \\
\text { derived } \\
\text { peptide } \\
\text { GP2 }\end{array}$ & $\begin{array}{l}\text { Vaccination Arm: GP2 + } \\
\text { GM-CSF }(\mathrm{N}=89) \\
\text { Control Arm: GM-CSF } \\
\text { alone }(\mathrm{N}=91)\end{array}$ & $\begin{array}{l}\text { HLA-A2+, HER2- } \\
\text { expressing, node- } \\
\text { positive or high- } \\
\text { risk node-negative }\end{array}$ & DFS, RR & $\begin{array}{l}\text { The estimated 5-year DFS: 88\% (vaccinated } \\
\text { group) versus } 81 \% \text { (control group) }(P=0.43) \text {; } \\
\text { 100\% (HER2 3+ vaccinated patients) versus } \\
\text { 89\% (HER2 3+ placebo patients) ( } P=0.03)\end{array}$ \\
\hline $\begin{array}{l}\text { US Military Cancer } \\
\text { Institute Clinical } \\
\text { Trials Group Study } \\
\text { I-04 (84) }\end{array}$ & I & Adjuvant & $\begin{array}{l}\text { HER2- } \\
\text { derived } \\
\text { peptide } \\
\text { GP2 }\end{array}$ & $\begin{array}{l}\text { Single arm: GP2 + GM- } \\
\text { CSF of different doses } \\
(\mathrm{N}=18)\end{array}$ & $\begin{array}{l}\text { HLA-A2+, HER2- } \\
\text { expressing, node- } \\
\text { negative }\end{array}$ & $\begin{array}{l}\text { Safety, } \\
\text { immune } \\
\text { response }\end{array}$ & $\begin{array}{l}\text { Immune response was induced in all the } \\
\text { enrolled patients. Toxicities were minimal. }\end{array}$ \\
\hline $\begin{array}{l}\text { NCT00524277 } \\
\text { (107) }\end{array}$ & $\|$ & Adjuvant & $\begin{array}{l}\text { HER2- } \\
\text { derived } \\
\text { peptide } \\
\text { AE37 }\end{array}$ & $\begin{array}{l}\text { Vaccination Arm: AE37 + } \\
\text { GM-CSF }(N=153) \\
\text { Control Arm: GM-CSF } \\
\text { alone }(\mathrm{N}=145)\end{array}$ & $\begin{array}{l}\text { HLA-A2+, HER2- } \\
\text { expressing, node- } \\
\text { positive or high- } \\
\text { risk node-negative }\end{array}$ & $\mathrm{RR}$ & $\begin{array}{l}\text { RR at } 25 \text {-month median follow-up: } 12.4 \% \\
\text { (vaccinated group) versus } 13.8 \% \text { (control } \\
\text { group) }(P=0.70) \text {. }\end{array}$ \\
\hline $\begin{array}{l}\text { US Military Cancer } \\
\text { Institute Clinical } \\
\text { Trials Group Study } \\
\text { I-03 (85) }\end{array}$ & 1 & Adjuvant & $\begin{array}{l}\text { HER2- } \\
\text { derived } \\
\text { peptide } \\
\text { AE37 }\end{array}$ & $\begin{array}{l}\text { Single arm: AE37 + GM- } \\
\text { CSF of different doses } \\
(\mathrm{N}=15)\end{array}$ & $\begin{array}{l}\text { HLA-A2+, HER2- } \\
\text { expressing, node- } \\
\text { negative }\end{array}$ & $\begin{array}{l}\text { Safety, } \\
\text { immune } \\
\text { response }\end{array}$ & $\begin{array}{l}\text { Immune response was induced in all the } \\
\text { enrolled patients. Toxicities were minimal. }\end{array}$ \\
\hline $\begin{array}{l}\text { NCT00399529 } \\
\text { (108) }\end{array}$ & $\|$ & Metastatic & HER2 & $\begin{array}{l}\text { Single arm: HER2 GM- } \\
\text { CSF-secreting tumor cell } \\
\text { vaccine }+ \\
\text { cyclophosphamide + } \\
\text { trastuzumab }(\mathrm{N}=20)\end{array}$ & $\begin{array}{l}\text { Stage IV, HER2- } \\
\text { expressing }\end{array}$ & $\begin{array}{l}\text { Safety, } \\
\text { CBR }\end{array}$ & $\begin{array}{l}\text { CBR at } 6 \text { months and } 1 \text { year was } 55 \% \text { and } \\
40 \% \text {, respectively. Toxicities were minimal. }\end{array}$ \\
\hline $\begin{array}{l}\text { NCT00140738 } \\
\text { (109) }\end{array}$ & $|/| \mid$ & Metastatic & HER2 & $\begin{array}{l}\text { Single arm: recombinant } \\
\text { HER2 protein + AS15 } \\
(\mathrm{N}=40)\end{array}$ & $\begin{array}{l}\text { Stage IV, HER2- } \\
\text { expressing }\end{array}$ & $\begin{array}{l}\text { Safety, } \\
\text { CBR }\end{array}$ & $\begin{array}{l}\text { Clinical activity was observed with } 2 / 40 \\
\text { objective responses and prolonged stable } \\
\text { disease for } 10 / 40 \text { patients. Immunization was } \\
\text { associated with minimal toxicity. }\end{array}$ \\
\hline $\begin{array}{l}\text { NCT02061332 } \\
\text { (110) }\end{array}$ & $\|$ & Neoadjuvant & HER2 & $\begin{array}{l}\text { Single arm: HER2 } \\
\text { dendritic cell vaccine with } \\
\text { different routes }(\mathrm{N}=27)\end{array}$ & $\begin{array}{l}\text { HER2-expressing } \\
\text { DCIS or early } \\
\text { invasive breast } \\
\text { cancer }\end{array}$ & $\begin{array}{l}\text { Safety, } \\
\text { immune } \\
\text { and clinical } \\
\text { response }\end{array}$ & $\begin{array}{l}\text { Vaccination by all injection routes was well } \\
\text { tolerated. There was no significant difference in } \\
\text { immune response rates by vaccination route. }\end{array}$ \\
\hline
\end{tabular}

CBR, clinical benefit rate; DCIS, ductal carcinoma in situ; DFS, disease-free survival; GM-CSF, granulocyte-macrophage colony-stimulating factor; HER2, human epidermal growth factor receptor 2; HLA, human leukocyte antigen; IHC, immunohistochemistry; RR, recurrence rate.

vaccination may lead to clinical benefits in patients with low HER2-expressing tumors, specifically TNBC.

\subsubsection{Protein-Based Vaccine}

As for the protein-based vaccine, in a phase 1 study, 29 patients with stage II-IV HER2-overexpressing breast and ovarian cancer were vaccinated with the intracellular domain of HER2 (amino acids 676-1255) plus GM-CSF (86). As a result, $89 \%$ of the patients developed HER2-specific T cell immunity, and HER2specific antibody immunity was observed in $82 \%$ of the patients. Cellular immunity was maintained for 9-12 months after completion of immunization in over half of the patients.
In another phase 1 trial, another recombinant HER2 protein with adjuvant AS15 was administered to 61 trastuzumab-naive patients with stage II-III HER2-overexpressing breast cancer after surgical resection and adjuvant therapy (122). Association was found between the vaccination dose, the immunization schedule, and the prevalence of HER2-specific humoral responses. The HER2-specific immunity was maintained for over 5 years in $6 / 8$ patients who received the highest dose of vaccination. In the metastatic setting, the same vaccine regimen was administered to 40 HER2-overexpressing metastatic breast cancer patients as first or second-line therapy following response to trastuzumab-based treatment as maintenance (109). 
TABLE 3 | Major clinical trials on breast cancer vaccines targeting non-HER2-related antigens.

\begin{tabular}{|c|c|c|c|c|c|c|}
\hline $\begin{array}{l}\text { Clinical Trial } \\
\text { Reference }\end{array}$ & $\begin{array}{c}\text { Trial } \\
\text { Phase }\end{array}$ & Setting & $\begin{array}{l}\text { Targeted } \\
\text { Tumor } \\
\text { Antigen }\end{array}$ & $\begin{array}{l}\text { Breast } \\
\text { Cancer } \\
\text { Subtype }\end{array}$ & $\begin{array}{l}\text { Primary } \\
\text { Objectives }\end{array}$ & Outcomes \\
\hline $\begin{array}{l}\text { NCT00003638 } \\
\text { (101) }\end{array}$ & III & Metastatic & STn & Stage IV & TTP, OS & $\begin{array}{l}\text { TTP: } 3.4 \text { months (treatment group) versus } 3.0 \text { months (control group) } \\
\text { ( } \mathrm{P}=0.35 \text { ). Median OS: } 23.1 \text { months (treatment group) versus } 22.3 \\
\text { months (control group) }(\mathrm{P}=0.91 \text { ). }\end{array}$ \\
\hline $\begin{array}{l}\text { Miles DW, } \\
\text { et al. (111) }\end{array}$ & $\|$ & Metastatic & STn & Stage IV & $\begin{array}{l}\text { Safety, immune and } \\
\text { clinical response }\end{array}$ & $\begin{array}{l}\text { Clinical activity was observed with 2/18 minor responses and stable } \\
\text { disease for } 5 / 18 \text { patients. Toxicities were minimal. }\end{array}$ \\
\hline $\begin{array}{l}\text { NCT00179309 } \\
\text { (112) }\end{array}$ & $\|$ & Metastatic & Mucin-1, CEA & Stage IV & PFS & $\begin{array}{l}\text { Median PFS: } 7.9 \text { months (vaccinated arm) versus } 3.9 \text { months (control } \\
\text { arm) }(P=0.09) \text {. }\end{array}$ \\
\hline $\begin{array}{l}\text { Svane IM, et al. } \\
\text { (113) }\end{array}$ & $\|$ & Metastatic & p53 & $\begin{array}{l}\text { Stage IV HLA- } \\
\text { A2+ }\end{array}$ & $\begin{array}{l}\text { Safety, immune and } \\
\text { clinical response }\end{array}$ & $\begin{array}{l}\text { Clinical activity was observed with } 8 / 19 \text { stable disease or minor } \\
\text { regression with } 11 / 19 \text { progressive disease. Toxicities were minimal. }\end{array}$ \\
\hline $\begin{array}{l}\text { Domchek SM, } \\
\text { et al. (114) }\end{array}$ & I & Metastatic & hTERT & $\begin{array}{l}\text { Stage IV HLA- } \\
\text { A2+ }\end{array}$ & Immune response & $\begin{array}{l}\text { High immune response was observed in } 9 / 16 \text { patients and non/low } \\
\text { response was seen in } 7 / 16 \text { patients. }\end{array}$ \\
\hline $\begin{array}{l}\text { NCT00807781 } \\
\text { (99) }\end{array}$ & 1 & Metastatic & $\begin{array}{l}\text { Mammaglobin- } \\
\text { A }\end{array}$ & $\begin{array}{l}\text { Stage IV HLA- } \\
\text { A2/A3+ }\end{array}$ & $\begin{array}{l}\text { Safety, immune } \\
\text { response }\end{array}$ & $\begin{array}{l}\text { No serious adverse events and a significant increase in the frequency } \\
\text { of MAM-A specific } C D 8^{+} T \text { cells after vaccination }(0.9 \% \text { vs. } 3.8 \% \text {, } \\
P<0.001) \text { was observed. }\end{array}$ \\
\hline $\begin{array}{l}\text { Avigan D, et al. } \\
\text { (115) }\end{array}$ & I & Metastatic & $\begin{array}{l}\text { Multiple } \\
\text { antigens }\end{array}$ & Stage IV & $\begin{array}{l}\text { Safety, clinical } \\
\text { response }\end{array}$ & $\begin{array}{l}\text { No significant toxicity or autoimmunity. Clinical activity was observed } \\
\text { with } 2 / 10 \text { disease regression and } 1 / 10 \text { disease stabilization. }\end{array}$ \\
\hline
\end{tabular}

CEA, carcino-embryonic antigen; HLA, human leukocyte antigen; hTERT, human telomerase reverse transcriptase; OS, overall survival; PFS, progression-free survival; STn, Sialyl-Tn; TTP, time to progression.

The vaccine was well-tolerated and clinical activity was observed with 2 objective responses and prolonged stable disease for 10 patients.

\subsubsection{Tumor Cell Vaccine}

A HER2-positive tumor cell vaccine that was modified to secret GM-CSF has been evaluated in clinical trials. A total of 28 patients with metastatic breast cancer received the vaccine in combination with cyclophosphamide and doxorubicin to test the hypothesis that the two chemotherapy drugs can enhance vaccine-induced immunity (87). HER2-specific DTH and antibody responses were observed with low toxicity in most patients, and the optimal dose of chemotherapy was cyclophosphamide at $200 \mathrm{mg} / \mathrm{m}^{2}$ and doxorubicin at $350 \mathrm{mg} / \mathrm{m}^{2}$. The vaccine was administered to 20 HER2-positive metastatic breast cancer patients with a low dose of cyclophosphamide $\left(300 \mathrm{mg} / \mathrm{m}^{2}\right)$ and weekly trastuzumab in another single-arm clinical trial (108). Augmented HER2-specific immunity was also detected by enhanced DTH and $\mathrm{CD}^{+} \mathrm{T}$ cell responses.

\subsubsection{DNA-Based Vaccine}

In a pilot phase 1 study, the DNA vaccine encoding a full-length signaling-deficient version of HER2 was injected together with GM-CSF and IL-2 to 8 patients with metastatic HER2-positive breast cancer who were also treated by trastuzumab (97). Treatment for 2 patients was discontinued after one vaccine cycle due to rapid tumor progression or disease-related complications. The vaccine was proven to be safe in the trial. Although no $\mathrm{T}$ cell responses towards HER2 were observed immediately after vaccination, a significant increase of $\mathrm{MHC}$ class-II restricted T cell responses to HER2 was detected at longterm follow-up.

Another multicenter phase 1 study using a DNA vaccine named V930 involved 33 patients with stage II-IV solid tumors expressing HER2 or CEA (98). V930 contained equal amounts of plasmids expressing the extracellular and transmembrane domains of HER2 and a plasmid expressing CEA fused to the B subunit of Escherichia coli heat-labile toxin. Patients were randomly assigned to receive V930 alone or V930 followed by V932, another adenovirus subtype- 6 viral vector vaccine coding for the same antigens. In spite of good tolerance in both approaches, no measurable cell-mediated immune response to CEA or HER2 was either detected.

Currently, ongoing clinical trials (NCT00393783, NCT00436254) are evaluating the safety and immunologic activity of DNA-based vaccines encoding different versions of HER2-derived protein in treating HER2-overexpressing breast cancer.

\subsubsection{DC-Based Vaccine}

The efficacy of a DC-based vaccine towards HER2 was examined in patients with HER2-overexpressing ductal carcinoma in situ (DCIS) prior to surgical resection (123). The DC vaccine was loaded with HER2 MHC class-I and class-II peptides and activated in vitro with IFN- $\gamma$ and bacterial lipopolysaccharides to produce cytokine IL-12. The 13 patients enrolled in the study showed high rates of HER2-specific sensitization for both IFN- $\gamma$ secreting $\mathrm{CD}^{+} \mathrm{T}$ cells $(85 \%)$ and $\mathrm{CD}^{+} \mathrm{T}$ cells $(80 \%)$ and induction of tumor-lytic antibodies. Interestingly, 7 patients demonstrated markedly decreased HER2 expression in surgical tumor specimens, suggesting a possible immunoediting process for HER2-expressing tumor cells. A follow-up trial in the neoadjuvant setting involving 54 HER2-positive patients with DCIS or early invasive breast cancer indicated that clinical and immune responses to the tumor did not vary significantly between different routes (intralesional versus intranodal versus intralesional-plus-intranodal) by which the same DC vaccine is administered (110).

In another clinical study, 7 patients with stage II-IV HER2overexpressing breast cancer were injected with autologous DCs pulsed with a peptide derived from the intracellular domain of 
HER2 after surgery and adjuvant therapy (124). HER2-specific antibodies were detected in six patients, and all of the seven participants were disease-free at a median follow-up of 5 years.

Clinical trials involving DC-based vaccines are moving forward currently. These trials use DCs pulsed with HER2derived peptide E75 plus trastuzumab and vinorelbine (NCT00266110), and DCs pulsed with HER2 peptides 369-377 and 689-697 (NCT00923143).

\subsection{Vaccines Targeting Non-HER2-Related Antigens}

Besides HER2 or HER2-related peptides, non-HER2-related antigens are also studied in vaccination for breast cancer, indicating opportunities of using cancer vaccines to treat HER2negative breast cancers. Mucins, human telomerase reverse transcriptase (hTERT), and p53 are some of the studied targets. Next, breast cancer vaccines targeting non-HER2-related antigens will be introduced in the order of their types.

\subsubsection{Carbohydrate Antigen Vaccine-Sialyl-Tn}

Theratope $^{\circledR}$, the STn-keyhole limpet hemocyanin (KLH) vaccine, is a synthetic STn conjugated to the KLH carrier protein. A significantly higher antibody level was observed in patients pretreated with a low dose of cyclophosphamide and vaccinated with STn-KLH in a randomized phase 2 trial (111). In the following double-blinded phase 3 study, a total of 1028 metastatic breast cancer patients across 126 centers in 10 countries were randomized to receive the STn-KLH vaccine or only KLH alone. Patients in both arms also received a low dose of cyclophosphamide $\left(300 \mathrm{mg} / \mathrm{m}^{2}\right)$ to increase the immunogenicity of the vaccine. The primary endpoint was time to progression (TTP) and overall survival (OS). Despite the fact that significant antibody titers specific for STn were produced in patients treated with the vaccine, no significant improvement in TTP or OS was observed in the trial (101). The TTP was 3.4 months in the treatment group and 3.0 months in the control group $(\mathrm{P}=0.353)$. The median survival time was 23.1 months and 22.3 months $(\mathrm{P}=0.916)$, respectively, in the treatment and control groups. Lack of more strict eligibility criteria might be part of the reason for the negative results in that only $30 \%-40 \%$ of the breast cancer express STn, and no detection of STn expression was performed on the patients enrolled in the study (125). A subgroup analysis showed that the vaccinated arm had longer TTP and OS compared with the control arm in patients receiving endocrine therapy, indicating using the STn-KLH vaccine in combination with the endocrine therapy might improve clinical outcomes (126).

\subsubsection{Peptide Vaccine-hTERT}

The hTERT is nearly universally overexpressed in human cancers, including breast cancer, and it can be recognized by $\mathrm{CD} 8^{+} \mathrm{T}$ cells. Nineteen patients with metastatic breast cancer received hTERT peptide vaccination, and high hTERT-specific $\mathrm{CD}^{+} \mathrm{T}$ cell responses were induced after vaccination in 9 participants (114). An exploratory analysis revealed that the median OS was significantly longer in the patients who achieved an immune response to hTERT compared with those who did not. Trials evaluating hTERT vaccines are underway in the metastatic setting
(NCT00573495 and NCT01660529) and the adjuvant setting (NCT02960594 and NCT00753415).

\subsubsection{DNA-Based Vaccine-MUC-1, Mammoglobin-A}

$\mathrm{PANVAC}$ is a recombinant poxviral-vector cancer vaccine consisting of a priming dose with recombinant vector and subsequent doses with recombinant fowlpox vector. Each vector encodes the transgenes for CEA and MUC-1 and transgenes for 3 human costimulatory molecules (B7.1, ICAM-1, and LFA3). In a phase 2 clinical trial, 48 patients with metastatic breast cancer of all subtypes were randomized to receive PANVAC plus docetaxel or docetaxel alone (112). A trend towards improvement in progression-free survival (PFS) was detected. The median PFS in the vaccinated arm was 7.9 months compared with 3.9 months in the control arm $(\mathrm{P}=0.09)$ at the median potential follow-up of 42.8 months.

Mammoglobin-A (MAM-A) is another breast cancerassociated antigen overexpressed in $40 \%$ to $80 \%$ of primary breast cancers (127). A phase I clinical trial of a MAM-A DNA vaccine was initiated to evaluate its safety and efficacy. In this study enrolling 14 patients with stable metastatic breast cancer, significant increase in the frequency of MAM-A specific $\mathrm{CD} 8^{+} \mathrm{T}$ cells and no severe adverse events were observed after vaccination. Exploratory analysis also suggested an improved 6-month PFS rate in the vaccinated patients compared with those who met all eligibility criteria but were not vaccinated because of HLA phenotype (53\% vs. 33\%, $\mathrm{P}=0.011$ ) (99).

\subsubsection{DC-Based Vaccine-p53}

The efficacy of a DC-based vaccine loaded with wild-type p53derived peptide and stimulated with IL- 4 and GM-CSF has been evaluated. This vaccine was administered in combination with lowdose IL-2 to 26 metastatic breast cancer patients in the study (113). Seven patients discontinued vaccination due to rapid disease progression or death. Eight of nineteen evaluable patients attained stable disease or minor regression while the rest of the patients had progressive disease, indicating the effect of p53-specific immune therapy. Surprisingly, the frequency of Treg cells was found to be almost doubled after vaccination in the analysis (128).

\subsubsection{DC-Tumor Cell Fusion Vaccine-Multiple Antigens} A phase I clinical trial evaluated the fusion cell vaccination in patients with metastatic breast cancer and renal cancer (115). A total of 32 breast cancer patients were enrolled in the study and vaccine generation was successful in 16 patients. Among them, 6 patients were withdrawn from the study before receiving the vaccine due to significant disease progression. The rest of the patients were vaccinated with autologous fusion cells. As a result, no significant treatment-related toxicity or autoimmunity was observed. Two patients exhibited disease regression and 1 patient had disease stabilization.

\section{COMBINATIONAL THERAPY OF BREAST CANCER VACCINE}

ICB has reformed the treatment strategy for some solid tumors, including melanoma and non-small cell lung cancer. As for breast 
cancer, ICB has already demonstrated its efficacy in treatment for metastatic TNBC (7). However, the addition of ICB to trastuzumab did not show a clinically significant improvement in PFS for HER2positive metastatic breast cancer and was associated with more adverse events (60). Currently, an area of active investigation is combining the vaccine with ICB to overcome cancer tolerance. As mentioned previously, ICB makes the effector immune cells able to attack the tumor cells by blocking the inhibitory receptors such as PD-1/PD-L1 and CTLA-4 (59). Results of some preclinical studies indicate that tumor vaccines will also upregulate the expression level of inhibitory receptors on the cell surface when activating $\mathrm{T}$ cells (129). One underlying mechanism is that increased IFN- $\gamma$ secreted by tumor-specific $\mathrm{T}$ cells can correspondingly upregulate the expression of PD-L1 on tumor cells and APCs, which is set initially to prevent over-amplification of the immune reactions occurring in the body (130). Therefore, the administration of ICB can probably relieve the immunosuppressive effect that attenuates anti-tumor immunity induced by vaccines. The combined use of breast cancer vaccine and ICB represents a promising strategy that may potentially enhance and prolong the duration of the immune response and ultimately lead to significant clinical benefits.

Additionally, applying cancer vaccines in combination with established therapies might also improve efficacy. Growing evidence has shown that some HER2-derived peptide vaccines may work synergistically when combined with anti-HER2 monoclonal antibodies (131). Studies indicates that chemotherapy and radiation therapy are associated with immunogenic cell death (132). Such immune response might help induce durable immune response when the therapies are applid in combination with cancer vaccines. Consistently, the effect of combining cancer vaccination with chemotherapy, targeted therapy, endocrine therapy, and even radiation therapy are also worth exploring $(104,133,134)$.

\section{CONCLUSION AND FUTURE PERSPECTIVE}

Active vaccination therapy for breast cancer has several theoretical advantages compared to conventional chemotherapy and antiHER2 immunotherapy via monoclonal antibodies: better tolerance, lower toxicity, and long-lasting immune response with tumor specificity (64). In addition, some vaccines can elicit immunity to tumors without any HER2 expression if the vaccine target is derived from non-HER2-related antigens.

However, clinical trials evaluating breast cancer vaccines have provided limited evidence of clinical benefits despite the successful induction of immune responses. It was demonstrated that the prognosis of patients who received vaccination is usually associated with the degree of immune responses (114). And in the initial E75 Phase 2 trial, immunity was noted to wane with time, and this corresponded with increased recurrences noted in the vaccine arm (103). Therefore a potential explanation for negative results to date is that the effective anti-tumor immunity stimulated by vaccines is not long-lasting enough to produce significant benefits in survival. The reason why the anti-tumor immune response fades so early may be attributed to the following factors: suboptimal vaccine formulations, the immune tolerance developed to specific tumor antigens, and the immune-suppressive microenvironment. Early trials have acknowledged that a HER2specific MHC class-I peptide epitope vaccine alone elicits only short-lived $\mathrm{CD}^{+} \mathrm{T}$ cell responses (135). In fact, as previously described, pre-existing immunity against HER2 has been detected in some patients. Nevertheless, the natural immune response is not strong enough to cultivate significant benefits due to immune tolerance. The immune tolerance that gradully builds in a longterm process might be a key factor to both the pre-existing immunity and the decreased immunity stimulated by vaccine. Hence, how to suppress immune tolerance for long and how to effectively exploit the natural immune response in the patients remains vital challenges to improve efficacy of breast cancer vaccines. Additionally, throughout the immunoediting process, the immunosuppressive effect will gradually outweigh the antitumor immunity as the tumor progresses. Even though the cancer vaccines manage to enhance the ability of the immune system to recognize specific tumor antigens, the effector immune cells such as CTLs might be incapable of efficiently eradicating the tumor cells in an immunosuppressive TME.

To overcome this issue, the optimal immunization dose and schedule, delivery routes, and choices of immunologic boosters need to be investigated. It was demonstrated that booster inoculations could maintain immunity, and those who received scheduled booster inoculations were less likely to recur (136). Moreover, the results of different peptide vaccines indicate that vaccine formulations should be tailored to the features of the tumor being targeted. Tolerance might be avoided by using subdominant epitopes with lower binding affinity against antigens with higher expression levels. For instance, E75, a dominant epitope of HER2, appears most effective in tumors expressing low degrees of HER2, while GP2, a subdominant epitope of HER2, shows more potential in HER2-overexpressing breast cancer in combination with trastuzumab. AE37, the MHC class-II targeted vaccine, shows the greatest efficacy in TNBC and may be helpful in all HLA subtypes (137).

The immune system maintains the delicate balance in our body to effectively remove non-self antigens and prevent autoimmune diseases at the same time. Despite the various obstacles that we encountered in the development of the breast cancer vaccine, the concept behind cancer vaccines that autologous immune systems can be mobilized to fight cancers has never been abandoned. Although the current results of clinical trials evaluating breast cancer vaccines are not satisfying, we believe novel strategies will eventually lead to improved efficacy as our understanding of cancer immunology deepens.

\section{AUTHOR CONTRIBUTIONS}

All authors wrote, read and approved the final manuscript.

\section{FUNDING}

Supported by grants from the National Natural Science Foundation of China (82072916), the 2018 Shanghai Youth 
Excellent Academic Leader, the Fudan ZHUOSHI Project, Chinese Young Breast Experts Research project (CYBER2021-A01).

\section{REFERENCES}

1. Sung H, Ferlay J, Siegel RL, Laversanne M, Soerjomataram I, Jemal A, et al. Global Cancer Statistics 2020: GLOBOCAN Estimates of Incidence and Mortality Worldwide for 36 Cancers in 185 Countries. CA Cancer J Clin (2021) 71(3):209-49. doi: 10.3322/caac.21660

2. Loibl S, Poortmans P, Morrow M, Denkert C, Curigliano G. Breast Cancer. Lancet (2021) 397(10286):1750-69. doi: 10.1016/S0140-6736(20)32381-3

3. Savas P, Salgado R, Denkert C, Sotiriou C, Darcy PK, Smyth MJ, et al. Clinical Relevance of Host Immunity in Breast Cancer: From TILs to the Clinic. Nat Rev Clin Oncol (2016) 13:228-41. doi: 10.1038/nrclinonc.2015.215

4. Criscitiello C, Esposito A, Trapani D, Curigliano G. Prognostic and Predictive Value of Tumor Infiltrating Lymphocytes in Early Breast Cancer. Cancer Treat Rev (2016) 50:205-7. doi: 10.1016/j.ctrv.2016.09.019

5. Emens LA, Ascierto PA, Darcy PK, Demaria S, Eggermont AMM, Redmond WL, et al. Cancer Immunotherapy: Opportunities and Challenges in the Rapidly Evolving Clinical Landscape. Eur J Cancer (2017) 81:116-29. doi: 10.1016/j.ejca.2017.01.035

6. Lipson EJ, Forde PM, Hammers HJ, Emens LA, Taube JM, Topalian SL. Antagonists of PD-1 and PD-L1 in Cancer Treatment. Semin Oncol (2015) 42:587-600. doi: 10.1053/j.seminoncol.2015.05.013

7. Schmid P, Adams S, Rugo HS, Schneeweiss A, Barrios CH, Iwata H, et al. Atezolizumab and Nab-Paclitaxel in Advanced Triple-Negative Breast Cancer. N Engl J Med (2018) 379:2108-21. doi: 10.1056/NEJMoa1809615

8. Emens LA. Breast Cancer Immunobiology Driving Immunotherapy: Vaccines and Immune Checkpoint Blockade. Expert Rev Anticancer Ther (2012) 12:1597-611. doi: 10.1586/era.12.147

9. Emens LA. Breast Cancer Immunotherapy: Facts and Hopes. Clin Cancer Res (2018) 24:511-20. doi: 10.1158/1078-0432.CCR-16-3001

10. Humphries C. Adoptive Cell Therapy: Honing That Killer Instinct. Nature (2013) 504:S13-15. doi: 10.1038/504S13a

11. Weiner LM. Building Better Magic Bullets-Improving Unconjugated Monoclonal Antibody Therapy for Cancer. Nat Rev Cancer (2007) 7:7016. doi: $10.1038 / \mathrm{nrc} 2209$

12. Coulie PG, Van den Eynde BJ, van der Bruggen P, Boon T. Tumour Antigens Recognized by T Lymphocytes: At the Core of Cancer Immunotherapy. Nat Rev Cancer (2014) 14:135-46. doi: 10.1038/nrc3670

13. van der Burg SH. Correlates of Immune and Clinical Activity of Novel Cancer Vaccines. Semin Immunol (2018) 39:119-36. doi: 10.1016/ j.smim.2018.04.001

14. Schreiber RD, Old LJ, Smyth MJ. Cancer Immunoediting: Integrating Immunity's Roles in Cancer Suppression and Promotion. Science (2011) 331:1565-70. doi: 10.1126/science.1203486

15. Riaz N, Havel JJ, Makarov V, Desrichard A, Urba WJ, Sims JS, et al. Et Al: Tumor and Microenvironment Evolution During Immunotherapy With Nivolumab. Cell (2017) 171:934-49.e916. doi: 10.1016/j.cell.2017.09.028

16. Chang CC, Pirozzi G, Wen SH, Chung IH, Chiu BL, Errico S, et al. Multiple Structural and Epigenetic Defects in the Human Leukocyte Antigen Class I Antigen Presentation Pathway in a Recurrent Metastatic Melanoma Following Immunotherapy. J Biol Chem (2015) 290:26562-75. doi: 10.1074/ jbc.M115.676130

17. Ribas A. Adaptive Immune Resistance: How Cancer Protects From Immune Attack. Cancer Discov (2015) 5:915-9. doi: 10.1158/2159-8290.CD-15-0563

18. Mittal D, Gubin MM, Schreiber RD, Smyth MJ. New Insights Into Cancer Immunoediting and Its Three Component Phases-Elimination, Equilibrium and Escape. Curr Opin Immunol (2014) 27:16-25. doi: 10.1016/j.coi.2014.01.004

19. O'Donnell JS, Teng MWL, Smyth MJ. Cancer Immunoediting and Resistance to T Cell-Based Immunotherapy. Nat Rev Clin Oncol (2019) 16:151-67. doi: 10.1038/s41571-018-0142-8

20. Teng MW, Galon J, Fridman WH, Smyth MJ. From Mice to Humans: Developments in Cancer Immunoediting. J Clin Invest (2015) 125:3338-46. doi: $10.1172 / \mathrm{JCI} 80004$

\section{ACKNOWLEDGMENTS}

The figures are created with Biorender.com.

21. Matsushita H, Vesely MD, Koboldt DC, Rickert CG, Uppaluri R, Magrini VJ, et al. Cancer Exome Analysis Reveals a T-Cell-Dependent Mechanism of Cancer Immunoediting. Nature (2012) 482:400-4. doi: 10.1038/nature10755

22. Linnemann C, van Buuren MM, Bies L, Verdegaal EM, Schotte R, Calis JJ, et al. High-Throughput Epitope Discovery Reveals Frequent Recognition of Neo-Antigens by CD4+ T Cells in Human Melanoma. Nat Med (2015) 21:81-5. doi: 10.1038/nm.3773

23. Schumacher TN, Schreiber RD. Neoantigens in Cancer Immunotherapy. Science (2015) 348:69-74. doi: 10.1126/science.aaa4971

24. Balachandran VP, Luksza M, Zhao JN, Makarov V, Moral JA, Remark R, et al. Identification of Unique Neoantigen Qualities in Long-Term Survivors of Pancreatic Cancer. Nature (2017) 551:512-6. doi: 10.1038/nature24462

25. Hollingsworth RE, Jansen K. Turning the Corner on Therapeutic Cancer Vaccines. NPJ Vaccines (2019) 4:7. doi: 10.1038/s41541-019-0103-y

26. Lee $\mathrm{CH}$, Yelensky R, Jooss K, Chan TA. Update on Tumor Neoantigens and Their Utility: Why It Is Good to Be Different. Trends Immunol (2018) 39:536-48. doi: 10.1016/j.it.2018.04.005

27. Ilyas S, Yang JC. Landscape of Tumor Antigens in T Cell Immunotherapy. J Immunol (2015) 195:5117-22. doi: 10.4049/jimmunol.1501657

28. Benvenuto M, Focaccetti C, Izzi V, Masuelli L, Modesti A, Bei R. Tumor Antigens Heterogeneity and Immune Response-Targeting Neoantigens in Breast Cancer. Semin Cancer Biol (2019) 72:65-75. doi: 10.1016/ j.semcancer.2019.10.023

29. Hammerl D, Smid M, Timmermans AM, Sleijfer S, Martens JWM, Debets R. Breast Cancer Genomics and Immuno-Oncological Markers to Guide Immune Therapies. Semin Cancer Biol (2018) 52:178-88. doi: 10.1016/ j.semcancer.2017.11.003

30. Solinas C, Aiello M, Migliori E, Willard-Gallo K, Emens LA. Breast Cancer Vaccines: Heeding the Lessons of the Past to Guide a Path Forward. Cancer Treat Rev (2020) 84:101947. doi: 10.1016/j.ctrv.2019.101947

31. Disis ML, Gooley TA, Rinn K, Davis D, Piepkorn M, Cheever MA, et al. Generation of T-Cell Immunity to the HER-2/Neu Protein After Active Immunization With HER-2/Neu Peptide-Based Vaccines. J Clin Oncol (2002) 20:2624-32. doi: 10.1200/JCO.2002.06.171

32. Disis ML, Knutson KL, Schiffman K, Rinn K, McNeel DG. Pre-Existent Immunity to the HER-2/Neu Oncogenic Protein in Patients With HER-2/ Neu Overexpressing Breast and Ovarian Cancer. Breast Cancer Res Treat (2000) 62:245-52. doi: 10.1023/A:1006438507898

33. Disis ML CE, McLaughlin G, Murphy AE, Chen W, Groner B, Jeschke M, et al. Existent T-Cell and Antibody Immunity to HER-2/Neu Protein in Patients With Breast Cancer. Cancer Res (1994) 54(1):16-20.

34. Rabinovich GA, Gabrilovich D, Sotomayor EM. Immunosuppressive Strategies That are Mediated by Tumor Cells. Annu Rev Immunol (2007) 25:267-96. doi: 10.1146/annurev.immunol.25.022106.141609

35. DeNardo DG, Coussens LM. Inflammation and Breast Cancer. Balancing Immune Response: Crosstalk Between Adaptive and Innate Immune Cells During Breast Cancer Progression. Breast Cancer Res (2007) 9:212. doi: $10.1186 /$ bcr 1746

36. Liyanage UK, Moore TT, Joo HG, Tanaka Y, Herrmann V, Doherty G, et al. Prevalence of Regulatory T Cells is Increased in Peripheral Blood and Tumor Microenvironment of Patients With Pancreas or Breast Adenocarcinoma. J Immunol (2002) 169:2756-61. doi: 10.4049/jimmunol.169.5.2756

37. Gabrilovich DI. Myeloid-Derived Suppressor Cells. Cancer Immunol Res (2017) 5:3-8. doi: 10.1158/2326-6066.CIR-16-0297

38. Qian BZ, Pollard JW. Macrophage Diversity Enhances Tumor Progression and Metastasis. Cell (2010) 141:39-51. doi: 10.1016/j.cell.2010.03.014

39. Zou W. Regulatory T Cells, Tumour Immunity and Immunotherapy. Nat Rev Immunol (2006) 6:295-307. doi: 10.1038/nri1806

40. Tanaka A, Sakaguchi S. Regulatory T Cells in Cancer Immunotherapy. Cell Res (2017) 27:109-18. doi: 10.1038/cr.2016.151

41. Nakamura R, Sakakibara M, Nagashima T, Sangai T, Arai M, Fujimori T, et al. Accumulation of Regulatory $\mathrm{T}$ Cells in Sentinel Lymph Nodes is a 
Prognostic Predictor in Patients With Node-Negative Breast Cancer. Eur J Cancer (2009) 45:2123-31. doi: 10.1016/j.ejca.2009.03.024

42. Gentles AJ, Newman AM, Liu CL, Bratman SV, Feng W, Kim D, et al. The Prognostic Landscape of Genes and Infiltrating Immune Cells Across Human Cancers. Nat Med (2015) 21:938-45. doi: 10.1038/nm.3909

43. Coffelt SB, Wellenstein MD, de Visser KE. Neutrophils in Cancer: Neutral No More. Nat Rev Cancer (2016) 16:431-46. doi: 10.1038/nrc.2016.52

44. DeNardo DG, Brennan DJ, Rexhepaj E, Ruffell B, Shiao SL, Madden SF, et al. Leukocyte Complexity Predicts Breast Cancer Survival and Functionally Regulates Response to Chemotherapy. Cancer Discov (2011) 1:54-67. doi: 10.1158/2159-8274.CD-10-0028

45. Bauer CA, Kim EY, Marangoni F, Carrizosa E, Claudio NM, Mempel TR. Dynamic Treg Interactions With Intratumoral APCs Promote Local CTL Dysfunction. J Clin Invest (2014) 124:2425-40. doi: 10.1172/JCI66375

46. Chinen T, Kannan AK, Levine AG, Fan X, Klein U, Zheng Y, et al. An Essential Role for the IL-2 Receptor in Treg Cell Function. Nat Immunol (2016) 17:1322-33. doi: $10.1038 /$ ni. 3540

47. Dranoff G. Cytokines in Cancer Pathogenesis and Cancer Therapy. Nat Rev Cancer (2004) 4:11-22. doi: 10.1038/nrc1252

48. Ghiringhelli F, Puig PE, Roux S, Parcellier A, Schmitt E, Solary E, et al. Tumor Cells Convert Immature Myeloid Dendritic Cells Into TGF-BetaSecreting Cells Inducing CD4+CD25+ Regulatory T Cell Proliferation. J Exp Med (2005) 202:919-29. doi: 10.1084/jem.20050463

49. Kobie JJ, Shah PR, Yang L, Rebhahn JA, Fowell DJ, Mosmann TR. T Regulatory and Primed Uncommitted CD4 T Cells Express CD73, Which Suppresses Effector CD4 T Cells by Converting 5'-Adenosine Monophosphate to Adenosine. J Immunol (2006) 177:6780-6. doi: 10.4049/jimmunol.177.10.6780

50. Allard B, Beavis PA, Darcy PK, Stagg J. Immunosuppressive Activities of Adenosine in Cancer. Curr Opin Pharmacol (2016) 29:7-16. doi: 10.1016/ j.coph.2016.04.001

51. Schwartz M, Zhang Y, Rosenblatt JD. B Cell Regulation of the Anti-Tumor Response and Role in Carcinogenesis. J Immunother Cancer (2016) 4:40. doi: 10.1186/s40425-016-0145-x

52. Sarvaria A, Madrigal JA, Saudemont A. B Cell Regulation in Cancer and Anti-Tumor Immunity. Cell Mol Immunol (2017) 14:662-74. doi: 10.1038/ cmi.2017.35

53. Ruffell B, Chang-Strachan D, Chan V, Rosenbusch A, Ho CM, Pryer N, et al. Macrophage IL-10 Blocks CD8+ T Cell-Dependent Responses to Chemotherapy by Suppressing IL-12 Expression in Intratumoral Dendritic Cells. Cancer Cell (2014) 26:623-37. doi: 10.1016/j.ccell.2014.09.006

54. Freeman GJ, Long AJ, Iwai Y, Bourque K, Chernova T, Nishimura H, et al. Et $\mathrm{Al}$ : Engagement of the PD-1 Immunoinhibitory Receptor by a Novel B7 Family Member Leads to Negative Regulation of Lymphocyte Activation. J Exp Med (2000) 192:1027-34. doi: 10.1084/jem.192.7.1027

55. Zou W, Chen L. Inhibitory B7-Family Molecules in the Tumour Microenvironment. Nat Rev Immunol (2008) 8:467-77. doi: 10.1038/ nri2326

56. Zou W, Wolchok JD, Chen L. PD-L1 (B7-H1) and PD-1 Pathway Blockade for Cancer Therapy: Mechanisms, Response Biomarkers, and Combinations. Sci Transl Med (2016) 8:328rv324. doi: 10.1126/scitranslmed.aad7118

57. Linsley PS, Bradshaw J, Greene J, Peach R, Bennett KL, Mittler RS. Intracellular Trafficking of CTLA-4 and Focal Localization Towards Sites of TCR Engagement. Immunity (1996) 4:535-43. doi: 10.1016/S1074-7613 (00)80480-X

58. Buchbinder E, Hodi FS. Cytotoxic T Lymphocyte Antigen-4 and Immune Checkpoint Blockade. J Clin Invest (2015) 125:3377-83. doi: 10.1172/ JCI80012

59. Pardoll DM. The Blockade of Immune Checkpoints in Cancer Immunotherapy. Nat Rev Cancer (2012) 12:252-64. doi: 10.1038/nrc3239

60. Emens LA, Esteva FJ, Beresford M, Saura C, De Laurentiis M, Kim S-B, et al. Trastuzumab Emtansine Plus Atezolizumab Versus Trastuzumab Emtansine Plus Placebo in Previously Treated, HER2-Positive Advanced Breast Cancer (KATE2): A Phase 2, Multicentre, Randomised, Double-Blind Trial. Lancet Oncol (2020) 21:1283-95. doi: 10.1016/S1470-2045(20)30465-4

61. Ladjemi MZ, Jacot W, Chardes T, Pelegrin A, Navarro-Teulon I. Anti-HER2 Vaccines: New Prospects for Breast Cancer Therapy. Cancer Immunol Immunother (2010) 59:1295-312. doi: 10.1007/s00262-010-0869-2
62. Butterfield LH. Cancer Vaccines. BMJ (2015) 350:h988. doi: 10.1136/ bmj.h988

63. Shumway NM, Ibrahim N, Ponniah S, Peoples GE, Murray JL. Therapeutic Breast Cancer Vaccines: A New Strategy for Early-Stage Disease. BioDrugs (2009) 23:277-87. doi: 10.2165/11313490-000000000-00000

64. Al-Awadhi A, Lee Murray J, Ibrahim NK. Developing Anti-HER2 Vaccines: Breast Cancer Experience. Int J Cancer (2018) 143:2126-32. doi: 10.1002/ ijc.31551

65. Rosalia RA, Quakkelaar ED, Redeker A, Khan S, Camps M, Drijfhout JW, et al. Dendritic Cells Process Synthetic Long Peptides Better Than Whole Protein, Improving Antigen Presentation and T-Cell Activation. Eur J Immunol (2013) 43:2554-65. doi: 10.1002/eji.201343324

66. Milani A, Sangiolo D, Montemurro F, Aglietta M, Valabrega G. Active Immunotherapy in HER2 Overexpressing Breast Cancer: Current Status and Future Perspectives. Ann Oncol (2013) 24:1740-8. doi: 10.1093/annonc/ mdt133

67. Reddish MA, Jackson L, Koganty RR, Qiu D, Hong W, Longenecker BM. Specificities of Anti-Sialyl-Tn and Anti-Tn Monoclonal Antibodies Generated Using Novel Clustered Synthetic Glycopeptide Epitopes. Glycoconj J (1997) 14:549-60. doi: 10.1023/A:1018576224062

68. Holmberg LA, Sandmaier BM. Vaccination With Theratope (STn-KLH) as Treatment for Breast Cancer. Expert Rev Vaccines (2004) 3:655-63. doi: 10.1586/14760584.3.6.655

69. Dols A, Smith JW2nd, Meijer SL, Fox BA, Hu HM, Walker E, et al. Vaccination of Women With Metastatic Breast Cancer, Using a Costimulatory Gene (CD80)-Modified, HLA-A2-Matched, Allogeneic, Breast Cancer Cell Line: Clinical and Immunological Results. Hum Gene Ther (2003) 14:1117-23. doi: 10.1089/104303403322124828

70. Dranoff G, Jaffee E, Lazenby A, Golumbek P, Levitsky H, Brose K, et al. Vaccination With Irradiated Tumor Cells Engineered to Secrete Murine Granulocyte-Macrophage Colony-Stimulating Factor Stimulates Potent, Specific, and Long-Lasting Anti-Tumor Immunity. Proc Natl Acad Sci U S A (1993) 90:3539-43. doi: 10.1073/pnas.90.8.3539

71. Yang B, Jeang J, Yang A, Wu TC, Hung CF. DNA Vaccine for Cancer Immunotherapy. Hum Vaccin Immunother (2014) 10:3153-64. doi: $10.4161 / 21645515.2014 .980686$

72. Lentz BR. PEG as a Tool to Gain Insight Into Membrane Fusion. Eur Biophys $J$ (2007) 36:315-26. doi: 10.1007/s00249-006-0097-z

73. Cheong SC, Blangenois I, Franssen JD, Servais C, Phan V, Trakatelli M, et al. Generation of Cell Hybrids. Via Fusogenic Cell Line J Gene Med (2006) 8:919-28. doi: 10.1002/jgm.906

74. Kanduser M, Usaj M. Cell Electrofusion: Past and Future Perspectives for Antibody Production and Cancer Cell Vaccines. Expert Opin Drug Delivery (2014) 11:1885-98. doi: 10.1517/17425247.2014.938632

75. Lee WT. Dendritic Cell-Tumor Cell Fusion Vaccines. Adv Exp Med Biol (2011) 713:177-86. doi: 10.1007/978-94-007-0763-4_11

76. Melero I, Gaudernack G, Gerritsen W, Huber C, Parmiani G, Scholl S, et al. Therapeutic Vaccines for Cancer: An Overview of Clinical Trials. Nat Rev Clin Oncol (2014) 11:509-24. doi: 10.1038/nrclinonc.2014.111

77. Clements CJ, Griffiths E. The Global Impact of Vaccines Containing Aluminium Adjuvants. Vaccine (2002) 20:S24-33. doi: 10.1016/S0264410X(02)00168-8

78. Jger E, Ringhoffer M, Dienes HP, Arand M, Karbach J, Jger D, et al. GranulocyteMacrophage-Colony-Stimulating Factor Enhances Immune Responses to Melanoma-Associated Peptides In Vivo. Int J Cancer (1996) 67:54-62. doi: 10.1002/(SICI) 1097-0215(19960703)67:1<54::AID-IJC11>3.0.CO;2-C

79. Hailemichael Y, Dai Z, Jaffarzad N, Ye Y, Medina MA, Huang XF, et al. Persistent Antigen at Vaccination Sites Induces Tumor-Specific CD8(+) T Cell Sequestration, Dysfunction and Deletion. Nat Med (2013) 19:465-72. doi: $10.1038 / \mathrm{nm} .3105$

80. Grun JL, Maurer PH. Different T Helper Cell Subsets Elicited in Mice Utilizing Two Different Adjuvant Vehicles: The Role of Endogenous Interleukin 1 in Proliferative Responses. Cell Immunol (1989) 121:134-45. doi: 10.1016/0008-8749(89)90011-7

81. Hercus TR, Thomas D, Guthridge MA, Ekert PG, King-Scott J, Parker MW, et al. The Granulocyte-Macrophage Colony-Stimulating Factor Receptor: Linking Its Structure to Cell Signaling and its Role in Disease. Blood (2009) 114:1289-98. doi: 10.1182/blood-2008-12-164004 
82. Yan WL, Shen KY, Tien CY, Chen YA, Liu SJ. Recent Progress in GM-CSFBased Cancer Immunotherapy. Immunotherapy (2017) 9:347-60. doi: 10.2217/imt-2016-0141

83. Peoples GE, Gurney JM, Hueman MT, Woll MM, Ryan GB, Storrer CE, et al. Clinical Trial Results of a HER2/neu (E75) Vaccine to Prevent Recurrence in High-Risk Breast Cancer Patients. J Clin Oncol (2005) 23:7536-45. doi: 10.1200/JCO.2005.03.047

84. Carmichael MG, Benavides LC, Holmes JP, Gates JD, Mittendorf EA, Ponniah S, et al. Results of the First Phase 1 Clinical Trial of the HER-2/ Neu Peptide (GP2) Vaccine in Disease-Free Breast Cancer Patients: United States Military Cancer Institute Clinical Trials Group Study I-04. Cancer (2010) 116:292-301. doi: 10.1002/cncr.24756

85. Holmes JP, Benavides LC, Gates JD, Carmichael MG, Hueman MT, Mittendorf EA, et al. Results of the First Phase I Clinical Trial of the Novel II-Key Hybrid Preventive HER-2/Neu Peptide (AE37) Vaccine. J Clin Oncol (2008) 26:3426-33. doi: 10.1200/JCO.2007.15.7842

86. Disis ML, Schiffman K, Guthrie K, Salazar LG, Knutson KL, Goodell V, et al. Effect of Dose on Immune Response in Patients Vaccinated With an Her-2/ Neu Intracellular Domain Protein-Based Vaccine. J Clin Oncol (2004) 22:1916-25. doi: 10.1200/JCO.2004.09.005

87. Emens LA, Asquith JM, Leatherman JM, Kobrin BJ, Petrik S, Laiko M, et al. Timed Sequential Treatment With Cyclophosphamide, Doxorubicin, and an Allogeneic Granulocyte-Macrophage Colony-Stimulating Factor-Secreting Breast Tumor Vaccine: A Chemotherapy Dose-Ranging Factorial Study of Safety and Immune Activation. J Clin Oncol (2009) 27:5911-8. doi: 10.1200/ JCO.2009.23.3494

88. Weber J, Sondak VK, Scotland R, Phillip R, Wang F, Rubio V, et al. Granulocyte-Macrophage-Colony-Stimulating Factor Added to a Multipeptide Vaccine for Resected Stage II Melanoma. Cancer (2003) 97:186-200. doi: 10.1002/cncr.11045

89. Serafini P, Carbley R, Noonan KA, Tan G, Bronte V, Borrello I. High-Dose Granulocyte-Macrophage Colony-Stimulating Factor-Producing Vaccines Impair the Immune Response Through the Recruitment of Myeloid Suppressor Cells. Cancer Res (2004) 64:6337-43. doi: 10.1158/00085472.CAN-04-0757

90. Slingluff CL Jr, Petroni GR, Olson WC, Smolkin ME, Ross MI, Haas NB, et al. Effect of Granulocyte/Macrophage Colony-Stimulating Factor on Circulating CD8+ and CD4+ T-Cell Responses to a Multipeptide Melanoma Vaccine: Outcome of a Multicenter Randomized Trial. Clin Cancer Res (2009) 15:7036-44. doi: 10.1158/1078-0432.CCR-09-1544

91. van den Boorn JG, Barchet W, Hartmann G. Nucleic Acid Adjuvants: Toward an Educated Vaccine. Adv Immunol (2012) 114:1-32. doi: 10.1016/ B978-0-12-396548-6.00001-9

92. Liu W, Tang H, Li L, Wang X, Yu Z, Li J. Peptide-Based Therapeutic Cancer Vaccine: Current Trends in Clinical Application. Cell Prolif (2021) 54: e13025. doi: 10.1111/cpr.13025

93. Paston SJ, Brentville VA, Symonds P, Durrant LG. Cancer Vaccines, Adjuvants, and Delivery Systems. Front Immunol (2021) 12:627932. doi: 10.3389/fimmu.2021.627932

94. Bos R, van Duikeren S, van Hall T, Lauwen MM, Parrington M, Berinstein NL, et al. Characterization of Antigen-Specific Immune Responses Induced by Canarypox Virus Vaccines. J Immunol (2007) 179:6115-22. doi: 10.4049/ jimmunol.179.9.6115

95. van den Hende M, van Poelgeest MI, van der Hulst JM, de Jong J, Drijfhout JW, Fleuren GJ, et al. Skin Reactions to Human Papillomavirus (HPV) 16 Specific Antigens Intradermally Injected in Healthy Subjects and Patients With Cervical Neoplasia. Int J Cancer (2008) 123:146-52. doi: 10.1002/ijc.23502

96. de Vos van Steenwijk PJ, van Poelgeest MI, Ramwadhdoebe TH, Lowik MJ, Berends-van der Meer DM, van der Minne CE, et al. The Long-Term Immune Response After HPV16 Peptide Vaccination in Women With LowGrade Pre-Malignant Disorders of the Uterine Cervix: A Placebo-Controlled Phase II Study. Cancer Immunol Immunother (2014) 63:147-60. doi: 10.1007/s00262-013-1499-2

97. Norell H, Poschke I, Charo J, Wei WZ, Erskine C, Piechocki MP, et al. Vaccination With a Plasmid DNA Encoding HER-2/Neu Together With Low Doses of GM-CSF and IL-2 in Patients With Metastatic Breast Carcinoma: A Pilot Clinical Trial. J Transl Med (2010) 8:53. doi: 10.1186/ 1479-5876-8-53
98. Diaz CM, Chiappori A, Aurisicchio L, Bagchi A, Clark J, Dubey S, et al. Phase 1 Studies of the Safety and Immunogenicity of Electroporated HER2/CEA DNA Vaccine Followed by Adenoviral Boost Immunization in Patients With Solid Tumors. J Transl Med (2013) 11:62. doi: 10.1186/1479-5876-11-62

99. Tiriveedhi V, Tucker N, Herndon J, Li L, Sturmoski M, Ellis M, et al. Safety and Preliminary Evidence of Biologic Efficacy of a Mammaglobin-a DNA Vaccine in Patients With Stable Metastatic Breast Cancer. Clin Cancer Res (2014) 20:5964-75. doi: 10.1158/1078-0432.CCR-14-0059

100. Sandoval F, Terme M, Nizard M, Badoual C, Bureau MF, Freyburger L, et al. Mucosal Imprinting of Vaccine-Induced CD8(+) T Cells is Crucial to Inhibit the Growth of Mucosal Tumors. Sci Transl Med (2013) 5:172ra120. doi: $10.1126 /$ scitranslmed. 3004888

101. Miles D, Roche H, Martin M, Perren TJ, Cameron DA, Glaspy J, et al. Phase III Multicenter Clinical Trial of the Sialyl-TN (STn)-Keyhole Limpet Hemocyanin (KLH) Vaccine for Metastatic Breast Cancer. Oncologist (2011) 16:1092-100. doi: 10.1634/theoncologist.2010-0307

102. Mittendorf EA, Lu B, Melisko M, Price Hiller J, Bondarenko I, Brunt AM, et al. Efficacy and Safety Analysis of Nelipepimut-S Vaccine to Prevent Breast Cancer Recurrence: A Randomized, Multicenter, Phase III Clinical Trial. Clin Cancer Res (2019) 25:4248-54. doi: 10.1158/1078-0432.CCR-18-2867

103. Mittendorf EA, Clifton GT, Holmes JP, Schneble E, van Echo D, Ponniah S, et al. Final Report of the Phase I/II Clinical Trial of the E75 (Nelipepimut-S) Vaccine With Booster Inoculations to Prevent Disease Recurrence in HighRisk Breast Cancer Patients. Ann Oncol (2014) 25:1735-42. doi: 10.1093/ annonc/mdu211

104. Clifton GT, Hale D, Vreeland TJ, Hickerson AT, Litton JK, Alatrash G, et al. Results of a Randomized Phase IIb Trial of Nelipepimut-S + Trastuzumab Versus Trastuzumab to Prevent Recurrences in Patients With High-Risk HER2 Low-Expressing Breast Cancer. Clin Cancer Res (2020) 26:2515-23. doi: 10.1158/1078-0432.CCR-19-2741

105. Mittendorf EA, Ardavanis A, Litton JK, Shumway NM, Hale DF, Murray JL, et al. Primary Analysis of a Prospective, Randomized, Single-Blinded Phase II Trial Evaluating the HER2 Peptide GP2 Vaccine in Breast Cancer Patients to Prevent Recurrence. Oncotarget (2016) 7:66192-201. doi: 10.18632/ oncotarget.11751

106. Patel SS, McWilliams DB, Patel MS, Fischette CT, Thompson J, Daugherty FJ. "Five Year Median Follow-Up Data From a Prospective, Randomized, Placebo-Controlled, Single-Blinded, Multicenter, Phase IIb Study Evaluating the Reduction of Recurrences Using HER2/neu Peptide GP2 + GM-CSF vs. GM-CSF Alone After Adjuvant Trastuzumab in HER2 Positive Women With Operable Breast Cancersnehal". In: In San Antonio Breast Cancer Symposium, vol. PS10-23. San Antonio, TX, United States (2020). Greenwich LifeSciences p. PS10-23.

107. Mittendorf EA, Ardavanis A, Symanowski J, Murray JL, Shumway NM, Litton JK, et al. Primary Analysis of a Prospective, Randomized, SingleBlinded Phase II Trial Evaluating the HER2 Peptide AE37 Vaccine in Breast Cancer Patients to Prevent Recurrence. Ann Oncol (2016) 27:1241-8. doi: 10.1093/annonc/mdw150

108. Chen G, Gupta R, Petrik S, Laiko M, Leatherman JM, Asquith JM, et al. A Feasibility Study of Cyclophosphamide, Trastuzumab, and an Allogeneic GM-CSF-Secreting Breast Tumor Vaccine for HER2+ Metastatic Breast Cancer. Cancer Immunol Res (2014) 2:949-61. doi: 10.1158/23266066.CIR-14-0058

109. Curigliano G, Romieu G, Campone M, Dorval T, Duck L, Canon JL, et al. A Phase I/II Trial of the Safety and Clinical Activity of a HER2-Protein Based Immunotherapeutic for Treating Women With HER2-Positive Metastatic Breast Cancer. Breast Cancer Res Treat (2016) 156:301-10. doi: 10.1007/ s10549-016-3750-y

110. Lowenfeld L, Mick R, Datta J, Xu S, Fitzpatrick E, Fisher CS, et al. Dendritic Cell Vaccination Enhances Immune Responses and Induces Regression of HER2(pos) DCIS Independent of Route: Results of Randomized Selection Design Trial. Clin Cancer Res (2017) 23:2961-71. doi: 10.1158/10780432.CCR-16-1924

111. Miles DW, Towlson KE, Graham R, Reddish M, Longenecker BM, TaylorPapadimitriou J, et al. A Randomised Phase II Study of Sialyl-Tn and DETOX-B Adjuvant With or Without Cyclophosphamide Pretreatment for the Active Specific Immunotherapy of Breast Cancer. Br J Cancer (1996) 74:1292-6. doi: 10.1038/bjc.1996.532 
112. Heery CR, Ibrahim NK, Arlen PM, Mohebtash M, Murray JL, Koenig K, et al. Docetaxel Alone or in Combination With a Therapeutic Cancer Vaccine (PANVAC) in Patients With Metastatic Breast Cancer: A Randomized Clinical Trial. JAMA Oncol (2015) 1:1087-95. doi: 10.1001/ jamaoncol.2015.2736

113. Svane IM, Pedersen AE, Johansen JS, Johnsen HE, Nielsen D, Kamby C, et al. Vaccination With P53 Peptide-Pulsed Dendritic Cells is Associated With Disease Stabilization in Patients With P53 Expressing Advanced Breast Cancer; Monitoring of Serum YKL-40 and IL-6 as Response Biomarkers. Cancer Immunol Immunother (2007) 56:1485-99. doi: 10.1007/s00262-0070293-4

114. Domchek SM, Recio A, Mick R, Clark CE, Carpenter EL, Fox KR, et al. Telomerase-Specific T-Cell Immunity in Breast Cancer: Effect of Vaccination on Tumor Immunosurveillance. Cancer Res (2007) 67:10546-55. doi: 10.1158/0008-5472.CAN-07-2765

115. Avigan D, Vasir B, Gong J, Borges V, Wu Z, Uhl L, et al. Fusion Cell Vaccination of Patients With Metastatic Breast and Renal Cancer Induces Immunological and Clinical Responses. Clin Cancer Res (2004) 10:4699-708. doi: 10.1158/1078-0432.CCR-04-0347

116. Peoples GE, Holmes JP, Hueman MT, Mittendorf EA, Amin A, Khoo S, et al. Combined Clinical Trial Results of a HER2/neu (E75) Vaccine for the Prevention of Recurrence in High-Risk Breast Cancer Patients: U.S. Military Cancer Institute Clinical Trials Group Study I-01 and I-02. Clin Cancer Res (2008) 14:797-803. doi: 10.1158/1078-0432.CCR-07-1448

117. Benavides LC, Gates JD, Carmichael MG, Patil R, Holmes JP, Hueman MT, et al. The Impact of HER2/neu Expression Level on Response to the E75 Vaccine: From U.S. Military Cancer Institute Clinical Trials Group Study I01 and I-02. Clin Cancer Res (2009) 15:2895-904. doi: 10.1158/10780432.CCR-08-1126

118. Mittendorf EA, Storrer CE, Foley RJ, Harris K, Jama Y, Shriver CD, et al. Evaluation of the HER2/neu-Derived Peptide GP2 for Use in a PeptideBased Breast Cancer Vaccine Trial. Cancer (2006) 106:2309-17. doi: 10.1002/ cncr.21849

119. Brown TA2nd, Mittendorf EA, Hale DF, Myers JW3rd, Peace KM, Jackson DO, et al. Prospective, Randomized, Single-Blinded, Multi-Center Phase II Trial of Two HER2 Peptide Vaccines, GP2 and AE37, in Breast Cancer Patients to Prevent Recurrence. Breast Cancer Res Treat (2020) 181:391-401. doi: 10.1007/s10549-020-05638-x

120. Humphreys RE, Adams S, Koldzic G, Nedelescu B, von Hofe E, Xu M. Increasing the Potency of MHC Class II-Presented Epitopes by Linkage to IiKey Peptide. Vaccine (2000) 18:2693-7. doi: 10.1016/S0264-410X(00) 00067-0

121. Gates JD, Clifton GT, Benavides LC, Sears AK, Carmichael MG, Hueman MT, et al. Circulating Regulatory T Cells (CD4+CD25+FOXP3+) Decrease in Breast Cancer Patients After Vaccination With a Modified MHC Class II HER2/neu (AE37) Peptide. Vaccine (2010) 28:7476-82. doi: 10.1016/ j.vaccine.2010.09.029

122. Limentani SA, Campone M, Dorval T, Curigliano G, de Boer R, Vogel C, et al. A Non-Randomized Dose-Escalation Phase I Trial of a Protein-Based Immunotherapeutic for the Treatment of Breast Cancer Patients With HER2-Overexpressing Tumors. Breast Cancer Res Treat (2016) 156:31930. doi: 10.1007/s10549-016-3751-x

123. Czerniecki BJ, Koski GK, Koldovsky U, Xu S, Cohen PA, Mick R, et al. Targeting HER-2/Neu in Early Breast Cancer Development Using Dendritic Cells With Staged Interleukin-12 Burst Secretion. Cancer Res (2007) 67:1842-52. doi: 10.1158/0008-5472.CAN-06-4038

124. Morse MA, Hobeika A, Osada T, Niedzwiecki D, Marcom PK, Blackwell KL, et al. Long Term Disease-Free Survival and T Cell and Antibody Responses in Women With High-Risk Her2+ Breast Cancer Following Vaccination Against Her2. J Transl Med (2007) 5:42. doi: 10.1186/1479-5876-5-42

125. Soares R, Marinho A, Schmitt F. Expression of Sialyl-Tn in Breast Cancer Correlation With Prognostic Parameters. Pathol - Res Pract (1996) 192:1181-6. doi: 10.1016/S0344-0338(96)80148-8
126. Ibrahim NK, Murray JL, Zhou D, Mittendorf EA, Sample D, Tautchin M, et al. Survival Advantage in Patients With Metastatic Breast Cancer Receiving Endocrine Therapy Plus Sialyl Tn-KLH Vaccine. Post Hoc Anal Large Randomized Trial J Cancer (2013) 4:577-84. doi: 10.7150/jca.7028

127. Sasaki E, Tsunoda N, Hatanaka Y, Mori N, Iwata H, Yatabe Y. Breast-Specific Expression of MGB1/mammaglobin: An Examination of 480 Tumors From Various Organs and Clinicopathological Analysis of MGB1-Positive Breast Cancers. Mod Pathol (2007) 20:208-14. doi: 10.1038/modpathol.3800731

128. Svane IM, Pedersen AE, Nikolajsen K, Zocca MB. Alterations in P53-Specific $\mathrm{T}$ Cells and Other Lymphocyte Subsets in Breast Cancer Patients During Vaccination With P53-Peptide Loaded Dendritic Cells and Low-Dose Interleukin-2. Vaccine (2008) 26:4716-24. doi: 10.1016/j.vaccine.2008.06.085

129. Fourcade J, Sun Z, Pagliano O, Chauvin JM, Sander C, Janjic B, et al. PD-1 and Tim-3 Regulate the Expansion of Tumor Antigen-Specific CD8(+) T Cells Induced by Melanoma Vaccines. Cancer Res (2014) 74:1045-55. doi: 10.1158/0008-5472.CAN-13-2908

130. Blank C, Brown I, Peterson AC, Spiotto M, Iwai Y, Honjo T, et al. PD-L1/ B7H-1 Inhibits the Effector Phase of Tumor Rejection by T Cell Receptor (TCR) Transgenic CD8+ T Cells. Cancer Res (2004) 64:1140-5. doi: 10.1158/ 0008-5472.CAN-03-3259

131. Mittendorf EA, Storrer CE, Shriver CD, Ponniah S, Peoples GE. Investigating the Combination of Trastuzumab and HER2/neu Peptide Vaccines for the Treatment of Breast Cancer. Ann Surg Oncol (2006) 13:1085-98. doi: 10.1245/ASO.2006.03.069

132. Fucikova J, Kepp O, Kasikova L, Petroni G, Yamazaki T, Liu P, et al. Detection of Immunogenic Cell Death and Its Relevance for Cancer Therapy. Cell Death Dis (2020) 11:1013. doi: 10.1038/s41419-020-03221-2

133. Middleton G, Silcocks P, Cox T, Valle J, Wadsley J, Propper D, et al. Gemcitabine and Capecitabine With or Without Telomerase Peptide Vaccine GV1001 in Patients With Locally Advanced or Metastatic Pancreatic Cancer (TeloVac): An Open-Label, Randomised, Phase 3 Trial. Lancet Oncol (2014) 15:829-40. doi: 10.1016/S1470-2045(14)70236-0

134. Barker CA, Postow MA. Combinations of Radiation Therapy and Immunotherapy for Melanoma: A Review of Clinical Outcomes. Int $J$ Radiat Oncol Biol Phys (2014) 88:986-97. doi: 10.1016/j.ijrobp.2013.08.035

135. Knutson KL, Schiffman K, Disis ML. Immunization With a HER-2/Neu Helper Peptide Vaccine Generates HER-2/Neu CD8 T-Cell Immunity in Cancer Patients. J Clin Invest (2001) 107:477-84. doi: 10.1172/JCI11752

136. Holmes JP, Clifton GT, Patil R, Benavides LC, Gates JD, Stojadinovic A, et al. Use of Booster Inoculations to Sustain the Clinical Effect of an Adjuvant Breast Cancer Vaccine: From US Military Cancer Institute Clinical Trials Group Study I-01 and I-02. Cancer (2011) 117:463-71. doi: 10.1002/ cncr. 25586

137. Clifton GT, Mittendorf EA, Peoples GE. Adjuvant HER2/neu Peptide Cancer Vaccines in Breast Cancer. Immunotherapy (2015) 7:1159-68. doi: 10.2217/ imt.15.81

Conflict of Interest: The authors declare that the research was conducted in the absence of any commercial or financial relationships that could be construed as a potential conflict of interest.

Publisher's Note: All claims expressed in this article are solely those of the authors and do not necessarily represent those of their affiliated organizations, or those of the publisher, the editors and the reviewers. Any product that may be evaluated in this article, or claim that may be made by its manufacturer, is not guaranteed or endorsed by the publisher.

Copyright $\odot 2022 \mathrm{Zhu}$ and $\mathrm{Yu}$. This is an open-access article distributed under the terms of the Creative Commons Attribution License (CC BY). The use, distribution or reproduction in other forums is permitted, provided the original author(s) and the copyright owner(s) are credited and that the original publication in this journal is cited, in accordance with accepted academic practice. No use, distribution or reproduction is permitted which does not comply with these terms. 